Jurnal Ekonomi Pembangunan

Volume 11, Nomor 2, Desember 2010, hlm.266-291

\title{
MODAL SOSIAL DALAM DINAMIKA PERKEMBANGAN SENTRA INDUSTRI LOGAM WARU SIDOARJO
}

\author{
Mit Witjaksono \\ Fakultas Ekonomi Universitas Negeri Malang \\ Jalan Semarang 5, Gedung E3, Lt. 2. Malang 65145, Indonesia Telepon/Fax +62-341-552888
}

Diterima 20 Oktober 2010/Disetujui 7 Nopember 2010

\begin{abstract}
The new institutional economics paradigm, qualitative-interpretive paradigm, case study strategy, and narrative interviewing were applied in this research in reconstructing conceptually and theoretically how the existence and roles of social capital within the context of the dynamics of SILOW (Sentra Industri Logam Waru) development since its beginning through the development of ASPILOW (Asosiasi Pengusaha Industri Logam Waru). Four distinct social capital perspectives and MBCA (Mutually Beneficial Collective Action are used as two proxies in reconstructing the existence and roles of social capital on the dynamics of SILOW development. Based on analytical reconstruction found that structurally and cognitively the existence and roles of social capital contribute significantly to the industry development of SILOW in five phases: the embryo of blacksmith center, the blacksmith center, the metal works center (SILOW), the SILOW-Synergy I, and the SILOW-Synergy II.
\end{abstract}

Keywords: new institutional economics, social capital, mutually beneficial collective action

\begin{abstract}
Abstrak: Paradigma ekonomi kelembagaan baru, paradigma kualitatif-interpretif, strategi studi kasus, dan wawancara naratif diterapkan dalam penelitian ini di dalam merekonstruksi secara konseptual dan teoritis keberadaan dan peran modal sosial dalam konteks dinamika perkembangan SILOW (Sentra Industri Logam Waru) sejak masa perintisan hingga lahirnya ASPILOW (Asosiasi Pengusaha Industri Logam Waru). Empat perspektif modal sosial dan MBCA (Mutually Beneficial Collective Action) digunakan sebagai proksi dalam merekonstruksi keberadaan dan peran modal sosial dalam dinamika perkembangan SILOW. Berdasarkan hasil rekonstruksi secara analitis ditemukan bahwa secara struktural dan kognitif keberadaan dan peran modal sosial memberi sumbangan signifikan terhadap perkembangan SILOW dalam lima fase: perintisan pande besi, sentra pande besi, sentra industri logam (SILOW), SILOW-Sinergi I, dan SILOW-Sinergi II.
\end{abstract}

Kata kunci: ekonomi kelembagaan baru, modal sosial, mutually beneficial collective action

\section{PENDAHULUAN}

Dari tiga sentra industri calon partisipan dalam proyek percontohan (pilot project) JICA (Japan International Cooperation Agency) tahun 20022003, Sentra Industri Logam Waru (selanjutnya disingkat: SILOW) dengan pusatnya di desa Ngingas, kecamatan Waru, Kabupaten Sidoarjo, Jawa Timur, terpilih karena memiliki keunggulan berdasarkan kriteria faktor-faktor peluang untuk tumbuh (growth opportunity factors) dan kapasitas perencanaan dan pengambilan-tindakan (planning and action-taking capacity). ${ }^{1}$ Pro-

1 Dua sentra industri logam yang lain: Tegal (Jawa Tengah), dan Sukabumi (Jawa Barat). Ada 10 sentra calon partisipan dalam proyek, terdiri dari 3 kelompok: (a) logam/komponen permesinan (3 sentra), (b) orientasi ekspor (4 sentra), dan (c) orientasi lokal (3 sentra). Orientasi ekspor terpilih sentra Mebel Serenan, Klaten (Jawa Tengah), dan orientasi lokal terpilih sentra Genteng, Kebumen (Jawa Tengah). Lihat JICA (2004a). The Study on Strenghthening Ca- 
yek percontohan nasional ini dilaksanakan oleh Tim JICA sebagai tindak lanjut dari misi pemerintah Jepang dalam membantu pemerintah Indonesia yang dirumuskan dalam Outline of Tentative Policy Recommendation for SME Promotion in Indonesia yang diwujudkan dalam bentuk kegiatan dengan judul The Study on Strengthening Capacity of SME Clusters in Indonesia (Urata, 2000). Tujuan proyek ini adalah mendorong berkembangnya sentra menjadi klaster yang dinamis menurut pendekatan model berlian (diamond) dari Michael Porter (1990) untuk peningkatan kapasitas faktor determinannya, dan klaster dinamis (dynamics cluster) dari Michael Best (1999) untuk proses pertumbuhannya. Sasaran akhir yang diharapkan dari proyek percontohan adalah adanya satu produk unggulan hasil kerjasama (collective/joint actions) dari unit-unit usaha yang ada di SILOW, yang statusnya menjadi industri pendukung dalam komponen permesinan (supporting industry in machinery components). Menurut laporan akhir yang disusun Tim JICA, motivasi untuk kerjasama antarUKM dari tiga partisipan selama proyek percontohan berlangsung, SILOW dinilai paling rendah dibanding sentra Mebel Serenan dan sentra Genteng Kebumen. Dugaan rendahnya motivasi bekerjasama antarUKM di SILOW didasarkan atas tiga faktor yang terkait dengan karakteristik SILOW (JICA, 2004a: 3-11): (i) heterogeneous nature of products limits the area of joint actions, (ii) most owners and workers commute from outside villages and are reluctant to have meetings outside of business hours, dan (iii) indifferent attitudes attributable to continuous assistance from donors and government have made SMEs less enthusiastic in participating in the pilot project. Latar heterogenitas produk yang membatasi kerjasama antarIKM, menurut Tim JICA karena lemahnya modal sosial di kalangan IKM. Dugaan ini didasarkan atas pengamatan sekilas ketika Tim JICA melakukan survei perbandingan dengan sentra industri logam yang ada di Pasuruan dan situasi lingkungan SILOW (JICA, 2004b: 1-5, 6). Tanpa modal sosial, menurut JICA, UKM yang ada di SILOW masih berstatus quo, karena seperti kebanyakan sentra IKM tidak lebih dari sekedar aglomerasi berbagai

pacity of SME Clusters in Indonesia. Final Report, hlm. 3-2 - 3-4.
UKM dengan jalinan sosial yang rentan dan mereka masih dalam keadaan tidak aktif (tidur), atau pada tahap bertahan hidup (Most SME clusters are just an agglomeration of enterprises with a fragile social fabric and are dormant or at the survival stage, JICA, 2004a: 4-1). Kondisi ini mirip dengan tipe sentra yang diidentifikasi Schmitz \& Nadvi (1999). Ketidakaktifan (dormancy) UKM dalam kasus SILOW, yang ditengarai sebagai akibat kurangnya modal sosial, memang diakui sebagai faktor yang luput dari kerangka dasar studi dan lokakarya awal proyek percontohan (JICA, 2004a: 4-15): Such dormancy is caused by a lack of social capital. Social capital is defined as intangible assests such as trust built and norms of reciprocity. ... Almost no existence of built trust has been initially observed in the pilot clusters. Unexpected results attained in Sidoarjo cluster is partly attributable to the fact that this factor of social capital has been over-looked in the baseline study and initial workshop.

Latar sinyalemen JICA tentang rendahnya modal sosial di kalangan UKM SILOW memotivasi peneliti melakukan penelitian lebih lanjut tentang bagaimana sebenarnya keberadaan dan peran modal sosial dalam konteks dinamika perkembangan SILOW. Apakah memang dugaan JICA tentang lemahnya modal sosial karena kurangnya kepercayaan dan norma resiprositas di kalangan UKM selama ini di dalam menjalin relasi bisnis dan sosial? Apakah bukan karena dalam waktu singkat UKM dihadapkan pada situasi dan kondisi yang menuntut saling kerjasama menciptakan satu produk unggulan dengan latar belakang perbedaan ragam produksi dan tingkat teknologinya, menyebabkan mereka tidak serta merta bersedia saling bekerjasama? Masih banyak pertanyaan kritis lainnya yang patut diajukan sehubungan dengan kesimpulan dan rekomendasi yang diajukan JICA dalam laporan akhir proyek percontohan.

Untuk menjawab pertanyaan tersebut perlu dilakukan penelitian eksploratif yang bisa merekonstruksi keberadaan serta peran modal sosial dalam dinamika perkembangan SILOW. Rekonstruksi latar historis dinamika perkembangan SILOW menjadi penting, karena dua alasan. Pertama, selain informasi sekilas tentang keunikan perkembangan SILOW yang telah 
dipaparkan di muka, menurut Hubert Schmitz ${ }^{2}$ tidaklah tepat jika membandingkan keberadaan kelembagaan antara yang ada di Waru-Sidoarjo (dalam hal ini SILOW) yang hanya punya satu koperasi dengan banyak anggota tetapi sedikit anggotanya yang aktif, dengan sentra genteng (dalam hal ini Kebumen) yang memiliki tiga bentuk organisasi kolektif yang semuanya memberi manfaat bagi anggotanya, karena tiap sentra memiliki sejarah dan dinamikanya sendiri ... The Sidoarjo-Waru metalworking cluster had one co-operative with many members but only a small number of active members. In contrast, in the roof-tile cluster we observed three different forms of collective organizations, all seemingly providing effective advantages to its members. Such organisational diversity should be encouraged. Each cluster has its own history and dynamics and it would be wrong to impose one model." (Schmitz \& Loebis, 2003: 5).

Kedua, tanpa mengetahui dan memahami latar historis dinamika perkembangan SILOW secara utuh, keberadaan dan peran modal sosialnya juga tidak akan bisa dipahami secara utuh, apapun kecenderungannya, misalnya apakah modal sosial menjadi semakin kuat, atau semakin lemah seperti sinyalemen JICA di atas. Dengan kata lain, rekonstruksi keberadaan dan peran modal sosial sangat bergantung pada konteksnya. ${ }^{3}$

Teori ekonomi kelembagaan baru (new institutional economics, NIE, atau EKB $)^{4}$ menjadi paradigma perspektif teoritis keberadaan dan peran modal sosial dalam konteks dinamika perkembangan SILOW. Kelembagaan (institu-

2 Hubert Schmitz, sebagai pakar pengembangan klaster dari IDS (Institute of Development Studies) University of Sussex England, diundang khusus oleh Tim JICA untuk meninjau dan memberi penilaian serta rekomendasi tentang proyek percontohan ketika kegiatan sudah berlangsung sekitar 7 bulan. Dibantu oleh Linda Loebis (dari Kementerian Perindustrian dan Perdagangan) ia menuliskan hasil peninjauannya dalam Laporan yang berjudul "Lessons from the JICA Project 'Strengthening the Capacity of SME Clusters in Indonesia'." (Juni 2003).

3 Misalnya Adam \& Roncevich, 2003, hlm. 160, menyebut context-specific; dan Ruuskanen, 2004, hlm. 4, menyatakan modal sosial sebagai fenomena yang bergantung pada konteksnya (dependent on its context).

4

Mubyarto, dalam Membangun Sistem Ekonomi, BPFE Yogyakarta, 2000, hlm. 255-257, tidak hanya memposisikan NIE/ EKB sebagai paradigma tetapi juga sebagai "Teori Besar" (grand theory). tions) didefinisikan secara umum sebagai suatu perangkat formal (hukum, kontrak, sistem politik, organisasi, pasar dan sebagainya) dan informal (norma, tradisi, kebiasaan, sistem nilai, agama, kecenderungan sosiologis, dan sebagainya), serta kaidah-kaidah tata-krama yang memfasilitasi koordinasi atau pengaturan relasi antarindividu atau kelompok. Lembaga-lembaga yang dimaksud lebih memberi kepastian di dalam interaksi manusia, dan memiliki pengaruh pada perilaku kita dan karenanya pada keluaran-keluaran seperti kinerja ekonomi, efisiensi, pertumbuhan dan perkembangan ekonomi (Kherallah \& Kirsten, 2001: 3-4).

Dua asumsi yang mendasari mengapa EKB dipandang sebagai paradigma yang lebih tepat dibandingkan paradigma ekonomi konvensional (ekonomi neoklasik). Pertama, konteks dinamika perkembangan SILOW tidak hanya mencakup aspek ekonomi dan bisnis saja, melainkan aspek-aspek lain yang inheren turut berperan, misalnya sosial, budaya, politik, hukum, dan latar historisnya. Aspek-aspek ini dalam paradigma neoklasik diabaikan, dalam paradigma EKB justru aspek-aspek ini menjadi basis dan orientasi analisis maupun interpretasinya. Kedua, modal sosial dalam paradigma EKB menjadi salah satu anak cabang ESB (Ekonomi Sosial Baru, NSE) dan EBT (Ekonomi Biaya Transaksi, TCE) (Khelarah \& Kirsten (2002: 114, lihat juga Yustika, 2006: 63). Menurut argumen dasar sosiologi ekonomi dan ekonomi kelembagaan, semua aktivitas dan organisasi ekonomi dalam masyarakat tradisional maupun masyarakat industri modern - termasuk SILOW - adalah melekat (embedded) di dalam lingkungan sosialnya. Argumen kelekatan (embeddedness), menurut Polanyi (1944), Granovetter (1985 \& 1992) dan Barber (1995) menandakan bahwa aktivitas ekonomi dalam organisasi tersebut tidaklah berkembang dalam suatu kekosongan sosial (social vacuum), tetapi aktivitas yang dipengaruhi oleh: (a) lembaga-lembaga yang terkonstruksi secara sosial (socially constructed institutions), (b) relasi personal antarpelakunya (the actors' personal relations), dan (c) struktur jaringan relasinya (the structure of the network of relations) (lihat Ruuskanen, 2004: 3). Bahkan, pada jaringan perusahaan multinasional yang beroperasi dalam ekonomi global pun berakar dalam relasi sosial dan 
lembaga-lembaga sosial (Castells, 1996). Dalam konteks kelekatan sosial itulah pemikiran di balik konsep modal sosial (social capital) menjadi penting, karena dianggap mampu menjelaskan bagaimana kelekatan sosial yang ada dalam tindakan-tindakan ekonomi mempengaruhi kinerja ekonomi suatu negara atau masyarakat. Coleman (1998), Putnam et al. (1993), dan OECD (2001), misalnya, menyatakan bahwa fitur-fitur tertentu yang ada pada suatu organisasi sosial, seperti jaringan (networks), norma (norms), dan kepercayaan (trust) dapat memperbaiki efisiensi kinerja masyarakat melalui fasilitasi koordinasi tindakan-tindakan ekonomi di dalam dan antar kelompok (Fukuyama, 1995, 1997, dan Ruuskanen, 2004: 3-4). Satu ciri yang selalu melekat dalam konsep modal sosial adalah bahwa ia bukan entitas tunggal (it is not a single entity ... dalam definisi Coleman, 1998: S98), tetapi entitas yang multi dimensi dan multi spektrum (Yustika, 2006: 200). Karena itu, tidak aneh bila sampai sekarang terdapat banyak ragam definisi tentang modal sosial, yang menjadi sumber perdebatan (misalnya: Adam \& Roncevic, 2003; Addler \& Kwon, 2002; Fine \& Lapavitsas, 2004; Lin, 1999; Portes, 1998; Quibria, 2003; Robison et al., 2000). Keragaman definisi disebabkan ragam pendekatan, fokus, orientasi, dan konsep yang dijadikan acuan dalam berbagai kajian, seperti yang dihimpun Dasgupta \& Serageldin (1999), dalam Social Capital: A Multifaceted Perspective. Dalam kajian empirispun terdapat banyak model (terutama yang kuantitatif) yang mengukur dampak modal sosial dalam konteks pembangunan, khususnya pembangunan ekonomi, misalnya Grootaert \& Van Bastelaer (2002) dalam Understanding and Measuring Social Capital: A Synthesis of Findings and Recommendations from the Social Capital Initiative. Dalam konteks preskripsi kebijakan pembangunan, Woolcock \& Narayan (2000) mengidentifikasi dan mengklasifikasikan berbagai pendekatan pengkajian modal sosial ke dalam empat perspektif (four distinct perspectives) yang dikemas dalam Social Capital: Implications for Development, Theory, Research, and Policy. Fungsi dan peran yang diidentifikasi dalam konsep modal sosial menurut Coleman (1988) dalam memfasilitasi pencapaian tujuan melalui pemanfaatan sumber daya secara kolektif diidentifikasi dan diformulasikan oleh Johnson et al., (2002), (Lihat Gambar 1).

Dalam konteks organisasi dan bisnis, modal sosial diartikan sebagai sumberdaya (resource) yang tersedia dalam suatu hubungan personal maupun bisnis, seperti dalam definisi Baker (2000: 1-2; 2001: 98): modal sosial adalah sumber-sumber daya yang tersedia di dalam dan diperoleh melalui jaringan relasi personal dan bisnis (misalnya: informasi, ide, petunjuk, peluang bisnis, modal finansial, kekuasaan dan pengaruh, dukungan emosional, niat baik, kepercayaan, dan kerjasama). Modal sosial sebagai sumberdaya seperti yang dirumuskan Baker sebelumnya (1990: 619), Bourdieu (1985: 248), Bourdieu \& Wackquant (1992: 119), dan

\begin{tabular}{|c|c|c|c|}
\hline Fungsi Umum: & Fasilitasi melalui: & Tujuan dan Per & anfaatan: \\
\hline $\begin{array}{l}\text { Memperoleh infor- } \\
\text { masi yang dibutuh- } \\
\text { kan }\end{array}$ & $\begin{array}{l}\text { Jaringan Informasi } \\
\text { (Information } \\
\text { Networks) }\end{array}$ & $\begin{array}{l}\text { 1. Identifikasi \& kontak klien potensial } \\
\text { 2. Akses informasi pasar } \\
\text { 3. Akses inputs }\end{array}$ & $\begin{array}{l}\text { 4. Memperoleh bantuan teknis } \\
\text { \& finansial }\end{array}$ \\
\hline $\begin{array}{l}\text { Mengurangi ketidak- } \\
\text { pastian \& pengawas- } \\
\text { an biaya transaksi }\end{array}$ & $\begin{array}{c}\text { Kepercayaan } \\
\text { (Trust) }\end{array}$ & $\begin{array}{l}\text { 1. Menjaga hubungan dengan klien } \\
\text { 2. Mengurangi biaya pengawasan \& } \\
\text { penegakan kontrak }\end{array}$ & $\begin{array}{l}\text { 3. Manajemen krisis } \\
\text { 4. Akses kredit }\end{array}$ \\
\hline $\begin{array}{l}\text { Memperoleh manfaat } \\
\text { kerjasama }\end{array}$ & $\begin{array}{l}\text { Tindakan Kolektif } \\
\text { (Collective Action) }\end{array}$ & $\begin{array}{l}\text { 1. Komersialisasi kolektif } \\
\text { 2. Penyediaan inputs secara kolektif } \\
\text { 3. Pengawasan \& penegakan } \\
\text { secara kolektif }\end{array}$ & $\begin{array}{l}\text { 5. Pembelanjaan secara kolektif } \\
\text { 6. Manajemen properti kolektif } \\
\text { 7. Kolusi } \\
\text { 8. Tindakan kolektif lain terkait }\end{array}$ \\
\hline
\end{tabular}

Sumber: Sintesis dari Johnson et al. (2002: 9-20), lihat juga catatan kaki Yustika (2006: 194).

Gambar 1. Peran Modal Sosial sebagai Fasilitator Pencapaian Tujuan Organisasi 
Tabel 1. Komplementaritas Struktur dan Kognisi Modal Sosial

\begin{tabular}{|c|c|c|c|}
\hline & Komplementer & Struktural & Kognitif \\
\hline & $\begin{array}{l}\text { Sumber dan manifes- } \\
\text { tasinya (sources and } \\
\text { manifestations) }\end{array}$ & $\begin{array}{l}\text { - Peran dan aturan (roles and rules) } \\
\text { - Jaringan dan relasi interpersonal } \\
\text { lainnya (networks and other } \\
\text { interpersonal relationships) } \\
\text { - Prosedur dan preseden/kejadian } \\
\text { (procedures and precedents) }\end{array}$ & $\begin{array}{l}\text { - Norma (norms) } \\
\text { - Nilai (values) } \\
\text { - Sikap (attitudes) } \\
\text { - Keyakinan (beliefs) }\end{array}$ \\
\hline (2) & $\begin{array}{l}\text { Cakupan/ranah } \\
\text { (domains) }\end{array}$ & Organisasi sosial & Budaya sipil (civic culture) \\
\hline (3) & $\begin{array}{l}\text { Faktor-faktor dinamis } \\
\text { (dynamic factors) }\end{array}$ & $\begin{array}{l}\text { - Kaitan horisontal (horizontal linkages) } \\
\text { - Kaitan vertikal (vertical linkages) }\end{array}$ & $\begin{array}{l}\text { Kepercayaan, solidaritas, kerjasama, } \\
\text { kedermawanan (trust, solidarity, } \\
\text { cooperation, generosity) }\end{array}$ \\
\hline & $\begin{array}{l}\text { Unsur bersama } \\
\text { (common elements) }\end{array}$ & \multicolumn{2}{|c|}{$\begin{array}{c}\text { Ekspektasi yang mengarah pada perilaku kerjasama, yang menghasilkan } \\
\text { keuntungan bersama (expectations that lead to cooperative behavior, which produces } \\
\text { mutual benefits) }\end{array}$} \\
\hline
\end{tabular}

Sumber: Adaptasi dari Uphoff (1999: 221), lihat juga Yustika (2006:200).

Nahapiet \& Ghoshal (1998: 243) [Lihat Adler \& Kwon, 2002: 20]. Menurut Norman Uphoff (1999), modal sosial sebagai fenomena bisa dipahami dengan cara membedakan dua kategori: (a) struktural (structural) dan (b) kognitif (cognitive). Dua kategori ini diartikan juga sebagai bentuk modal sosial (forms of social capital) (Grootaert \& Van Bastelaer, 2002: 508). Kajian yang dilakukan Uphoff (1999) disajikan dalam Tabe1 1 dan Gambar 2.

Modal sosial dalam organisasi perusahaan dewasa ini semakin penting. Menurut Emily Sims (2006) dalam konteks peningkatan produktivitas dan daya saing suatu organisasi usaha, modal sosial menduduki posisi dan peran setara dengan modal-modal yang lain (modal ekonomi dan modal manusia). Modal ekonomi, modal manusia, dan modal sosial secara bersama dan saling bergantung menjadi sumber produktivitas dan daya saing suatu perusahaan. Modal ekonomi diperlukan untuk produksi dan distribusi. Modal manusia yang

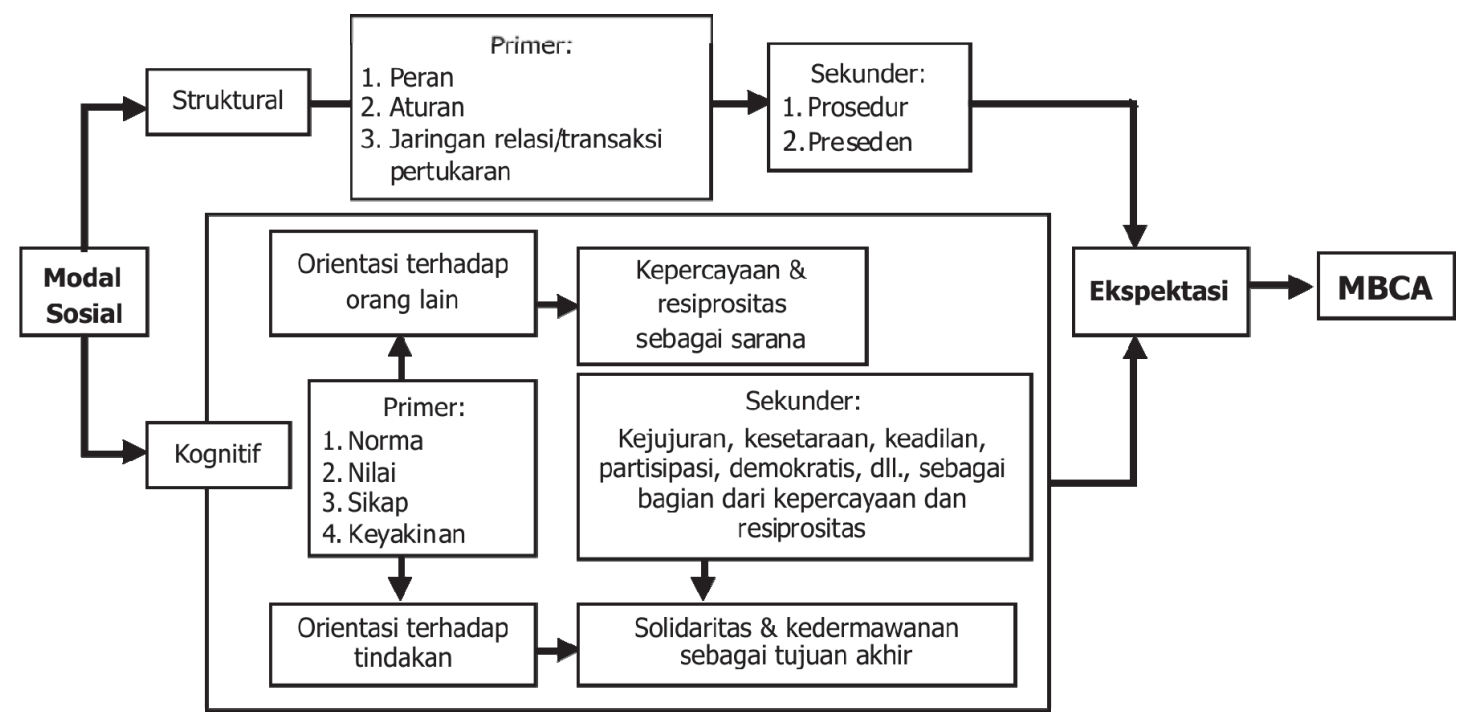

Sumber: Sintesis peneliti dari Uphoff (1999: 240-243).

Gambar 2. Dimensi Struktural dan Kognitif Modal Sosial dalam MBCA 
berupa keterampilan dan kompetensi melekat dalam tenaga kerja. Modal sosial adalah tingkat kepercayaan, komunikasi, dan kerjasama yang ada di dalam perusahaan, dan menjadi penentu akhir keberhasilan modal ekonomi dan modal manusia yang diinvestasikan dalam perusahaan, seperti yang ia rumuskan berikut (Sims, 2006: 39): The source of productivity and competitiveness is capital - economic, human, and social. Economic capital ... needed for production and distribution. Human capital is the skills, knowledge and competence embeded in the workforce. Social capital is the level of trust, communication and cooperation that exists within an enterprise.

The value of firm's investment in economic capital depends on its level of human capital ..., however, that value of firm's investment in human capital in turn depends directly on its investment in social capital. Without trust, communication and cooperation a firm is unable to make the most of its human capital, hence its economic capital.

Tingkat kepercayaan antara pekerja dan manajer dalam setiap momen pekerjaan sangat dipengaruhi oleh kesediaan mereka untuk berkomunikasi secara efektif. Keefektifan komunikasi pada gilirannya menentukan seberapa jauh mereka akan bekerjasama untuk meningkatkan produktivitas. Keberhasilan (kegagalan) dalam kerjasama di antara mereka akan menentukan tingkat kepercayaan pada momen berikutnya. Proposisi serupa juga telah diartikulasikan oleh Akdere (2005) dan Akdere \& Roberts (2008) dalam memposisikan modal sosial sebagai salah satu determinan ekonomi dalam pengembangan sumberdaya manusia (SDM) organisasi usaha. Ada saling keterkaitan antara modal sosial pada level individual, tim/kelompok, dan kinerja organisasional suatu perusahaan. Dalam suatu lingkungan organisasional, modal sosial di atas dapat berada di lingkungan karyawan (micro level), di lingkungan tim/kelompok kerja (meso level), dan dalam setting organisasional (macro level). Keterkaitan saling melingkupi (overarching): pada level individual, sesama karyawan menumbuh-kembangkan rasa dan hubungan saling percaya dan memperoleh manfaat dari relasi saling percaya; pada level tim/kelompok, dengan adanya hubungan saling percaya tadi, tim/kelompok akan terdorong untuk semakin kompak (modal sosialnya semakin berkembang); dan pada level organisasi, de- ngan modal sosial yang berkembang di kalangan individu dan tim/kelompok, maka di dalam organisasi akan tumbuh budaya kerja di mana karyawan secara individual merasa ikut memiliki, pada gilirannya, meningkatkan kepuasan kerja dan komitmen karyawan terhadap organisasi usaha.

\section{METODE PENELITIAN}

\section{Fokus Penelitian}

Dua pertanyaan yang menjadi fokus penelitian ini: (1) Bagaimana sebenarnya dinamika perkembangan SILOW secara konseptual dan teoritis dapat direkonstruksi berdasarkan penuturan pelaku sejarah? dan (2) Bagaimana keberadaan dan peran modal sosial dalam dinamika perkembangan SILOW dapat direkonstruksi secara konseptual dan teoritis berdasarkan penuturan pelaku usaha?

\section{Latar Setting Informan Kunci dan Narrative Interviewing}

Ada dua sumber yang bisa memberikan informasi sekitar sejarah SILOW secara lebih lengkap. Kedua sumber yang dimaksud ternyata pewaris dan penerus dari pendiri usaha pande besi pertama dan sekaligus sebagai perintis pengembangan sentra pande besi di Ngingas: (1) Ahmad Toyib Abdul Kadir (ATAK) dan (2) Moch. Abbas Abdul Kadir (ABAS). ATAK meninggal pada tahun 1998. Tinggal ABAS yang bisa menjawab pertanyaan penelitian pertama. Untuk menjawab pertanyaan kedua, selain penuturan dari informan kunci pertama (ABAS), penggalian informasi lebih lanjut diperkaya dari penuturan empat informan kunci berikut, semuanya pelaku usaha di lingkungan SILOW. Dua informan kunci masih ada hubungan keluarga dengan ABAS, yang berarti masih keturunan dari pendiri pande besi dan perintis sentra pande besi: (1) Imam Chambali AT (CHAM) dan (2) Miftakhul Ulum (MITA). Informan kunci (1) adalah anak ATAK, yang meneruskan usaha bapaknya: PT. Atak Otomotif Indo Metal. Informan kunci (2) adalah sepupu CHAM, yang bergabung dengan CHAM, sebagai Direktur Operasional, dan saat ini berperan pula sebagai Ketua ASPILOW (sejak 2006). Dua informan 
kunci berikutnya tidak ada pertalian keluarga dengan ABAS, bahkan berasal dari luar Ngingas, tetapi mereka berdua pernah ikut ABAS sebagai karyawan dan partner kerja: (1) Imam Syafii Siddiq (ISKA) dan (2) Artono (ARTO). Untuk memperoleh informasi yang berasal dari pengalaman, pengetahuan, pemahaman, dan pandangan pelaku sejarah (pertanyaan pertama) dan pelaku usaha (pertanyaan kedua), pendekatan yang relevan adalah mendengarkan, merekam, menganalisis, dan merekonstruksi apa yang dituturkan pelaku. Salah satu cara yang cocok melalui teknik wawancara naratif (narrative interviewing). Naratif berasal dari bahasa Latin: narrare, yang artinya melapor/menyampaikan suatu kisah/cerita (to report, to tell a story) (Bauer, 1987/1996 dan Jovchelovitch \& Bauer, 2000/2007). Wawancara naratif (selanjutnya disingkat: $\mathrm{WN}$ ) adalah teknik yang dilakukan dengan setting bagaimana orang yang diwawancarai (informan) bersedia menuturkan peristiwa atau pengalamannya guna merekonstruksi peristiwa/kejadian sosial dari perspektif informan selangsung mungkin (Its basic idea is to reconstruct social events from the perspective of informants as direct as possible) (Bauer, 1996: 2). ${ }^{5}$ (Lihat Kerangka Pikir dan Kerja Penelitian dalam Lampiran A Gambar 10).

\section{HASIL DAN PEMBAHASAN}

\section{Dinamika Perkembangan SILOW dalam Perspektif Komunitas}

Secara konfiguratif dinamika perkembangan SILOW disintesiskan dalam Peta Dinamika Perkembangan SILOW (Lampiran B) yang terkonstruksi dalam lima fase perubahan: (1) Rintisan Sentra Pande Besi (RSPB), (2) Sentra Pande Besi Waru (SPBW), (3) Sentra Industri Logam Waru (SILOW), (4) SILOW-Sinergi I, dan (5) SILOWSinergi II.

5 Secara sistematis teknik WN dikenalkan oleh F. Schutze pada tahun 1977: Die Technick des Narrativen Interviews in Interaktions-feldstudien - dargestellt an einem Projekt zur Erforschung von Kommunikativen Machtstrukturen. Unpublished manuscript. University of Bielefeld, Department of Sociology. Lihat dalam Bauer (1996), Jovchelovitch \& Bauer (2000/ 2007), dan Scheibelhofer (2005).

\section{Dinamika Perkembangan SILOW dalam Perspektif Perusahaan Pelopor}

Dari analisis tematik (thematic fields, dalam Rosenthal, 1993: 61) rekaman WN tiap informan kunci, diperoleh lima tema yang menjadi faktor dinamis pada masing-masing perusahaan pelopor. Tiga tema berkaitan dengan latar historis, motif dan konsep bisnis. Dua tema berikutnya berhubungan dengan modal sosial dan persepsinya terhadap keberadaan ASPILOW. Perbedaan dan kemiripan dalam lima aspek dinamis tersebut disintesakan ke dalam Profil Dinamika Perkembangan Perusahaan Pelopor SILOW (Lampiran C).

\section{Keberadaan dan Peran Modal Sosial dalam Perspektif Komunitas SILOW}

Jika keberadaan modal sosial dalam fase-fase perkembangan SILOW dianalisis menurut latar motif utama, dan disejajarkan dengan empat pespektif modal sosial menurut klasifikasi Woolcock \& Narayan (1999), maka dapat sintesiskan sebagaimana tampak dalam Gambar 3.

Fase 1 termasuk dalam perspektif komunitarian, karena latar motif utama pembentukan "Persatuan Pande Indonesia" (PPI) adalah untuk mengikat para pande besi yang semakin banyak jumlahnya di Ngingas (setelah diinisiasi oleh tiga serangkai: Abdul Kadir, Ashari, dan Mahfud). Sebetulnya Abdul Kadir dalam mendirikan pande besi dan mengajak Ashari dan Mahfud, bukan semata motif ekonomi, tetapi ada misi syiar agama dalam rangka menghilangkan kebiasaan buruk di kalangan masyarakat petani desa Ngingas waktu itu. Dua misi dikemas jadi satu dan selanjutnya dilembagakan ke dalam PPI (Persatuan Pande Indonesia). Fase 2 masuk dalam klasifikasi perspektif jaringan, karena bersamaan dengan makin kuatnya syiar agama yang dipelopori Abdul Kadir, dan pemerintah mulai campur tangan terhadap keberadaan PPI (mulai Pemilu pertama, 1955), Abdul Kadir mengambil inisiatif untuk mengikat PPI ke dalam jaringan antarpengusaha Islam dengan mendirikan "Persatuan Pengusaha Islam Indonesia" (PPII). Secara implisit bisa diduga dalam hal ini, bahwa PPI, yang sebelumnya lebih berorientasi ikatan horisontal (horizontal-bonding) antarsesama pengusaha pande besi, oleh 


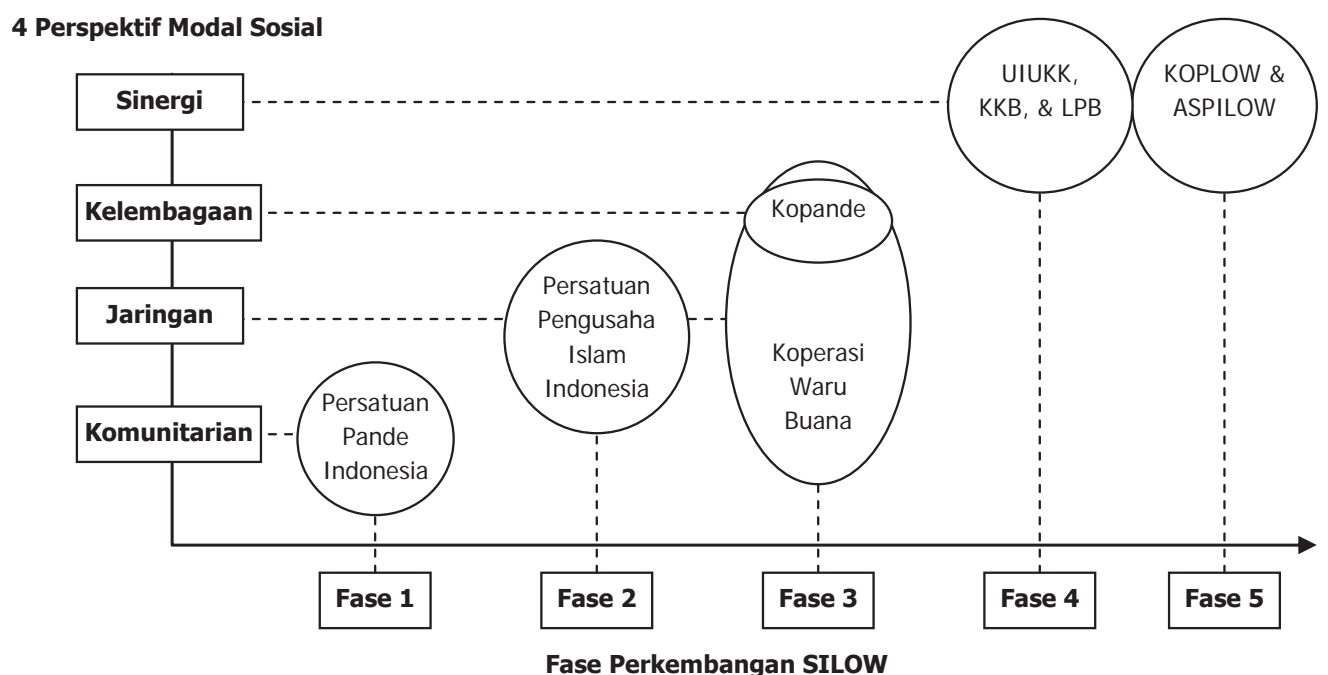

Sumber: Disintesiskan dari rekaman WN.

Gambar 3. Keberadaan Modal Sosial (Struktural) dalam Dinamika Perkembangan SILOW

Abdul Kadir ditingkatkan perannya secara vertikal dihubungkan dengan kelompok peng-

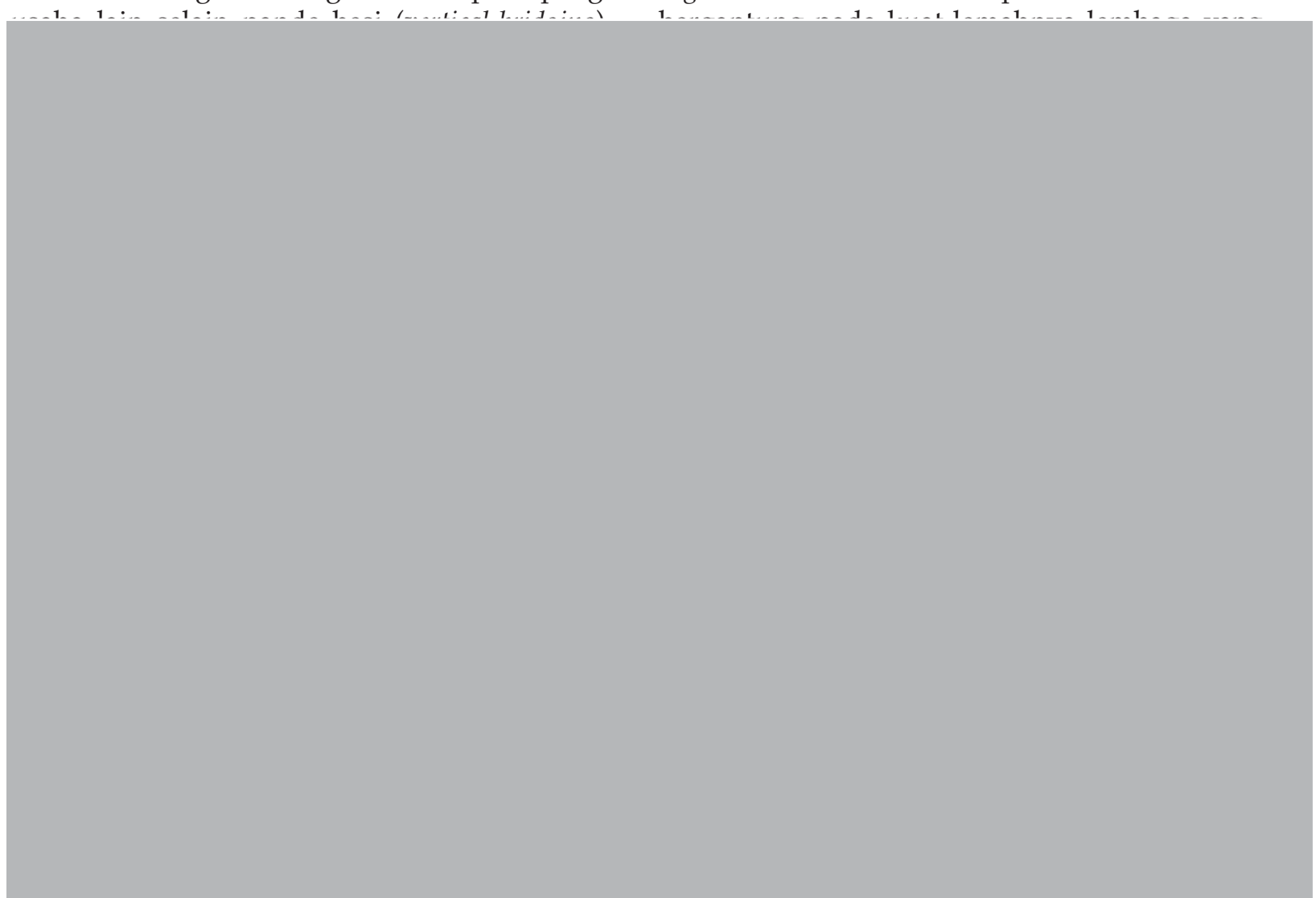

(1999), Fase 3 termasuk dalam perspektif kelembagaan. Keberadaan dan peran modal sosial

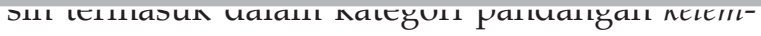
bagaan. KWBP menjadi sentral bagi dinamika

6 Menurut ABAS, memang ayah dan kakaknya (Abdul Kadir \& Ridwan) aktivis "Masyumi" waktu itu. 


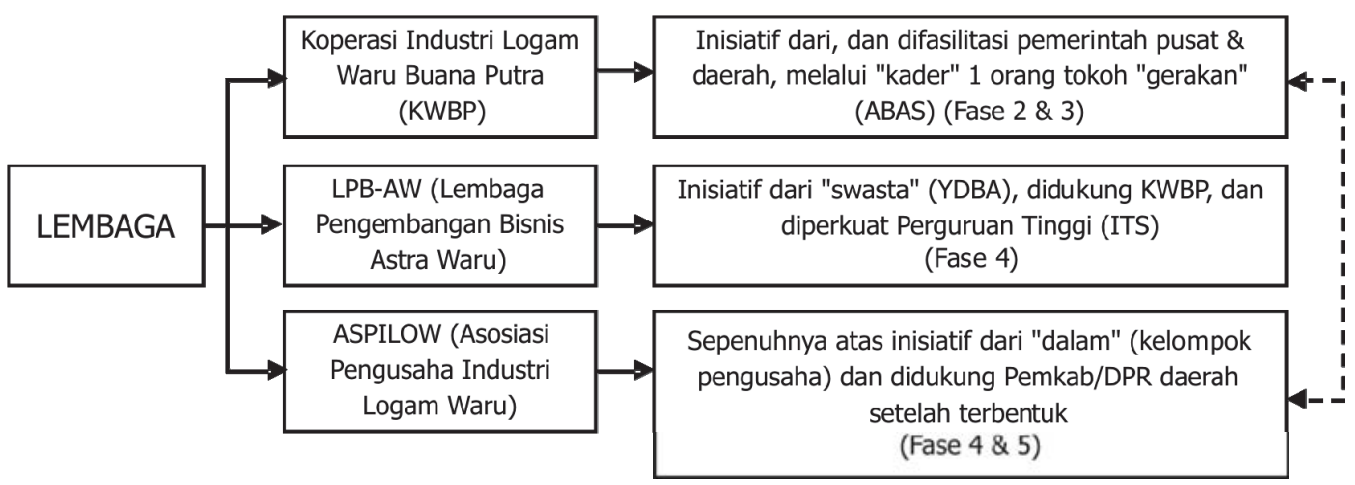

Sumber: Direkonstruksi dari rekaman WN.

Gambar 4. Latar Inisiatif dan Dukungan Pembentukan Kelembagaan Modal Sosial

kelembagaan lewat KWBP memang difasilitasi pemerintah, tetapi tidak lepas dari peran sentral ABAS. Akan tetapi, jika dianalisis bagaimana ABAS membangun koneksi dengan birokrat di Jakarta (Departemen Perindustrian dan Departemen Koperasi), sebetulnya situasi itu masih dalam kategori perspektif jaringan (network views). Karena itu dalam Gambar 3 posisi KWBP sebagian besar pada jaringan, sebagian kecil pada lembaga. Fase 4 dan 5 pada dasarnya sama, sudah memasuki kategori perspektif sinergi (synergy views). Perspektif sinergi yang menyatukan pandangan jaringan dan kelembagaan, pada Fase 4 nampak jelas implementasinya pada rangkaian proses terbentuknya UIUKK, KKB Astra Waru, LPB-Astra Waru, demikian halnya dengan proses terbentuknya KOPLOW, ASPILOW, hingga sinergi dengan Pemkab Sidoarjo yang melahirkan PT. DMN (Delta Mandiri Nugraha) (Periksa Lampiran B). Dari tiga lembaga yang sekarang eksis (KWBP, LPBAW, dan ASPILOW), menurut latar inisiatif dan dukungan pembentukannya berbeda seperti tampak pada Gambar 4.

\section{Modal Sosial dalam Perspektif Perusahaan Pelopor SILOW}

Dari sintesis rekonstruksi dinamika perkembangan tiga perusahaan pelopor SILOW ternyata terdapat kesamaan mendasar mengenai pendekatan masing-masing perusahaan di dalam
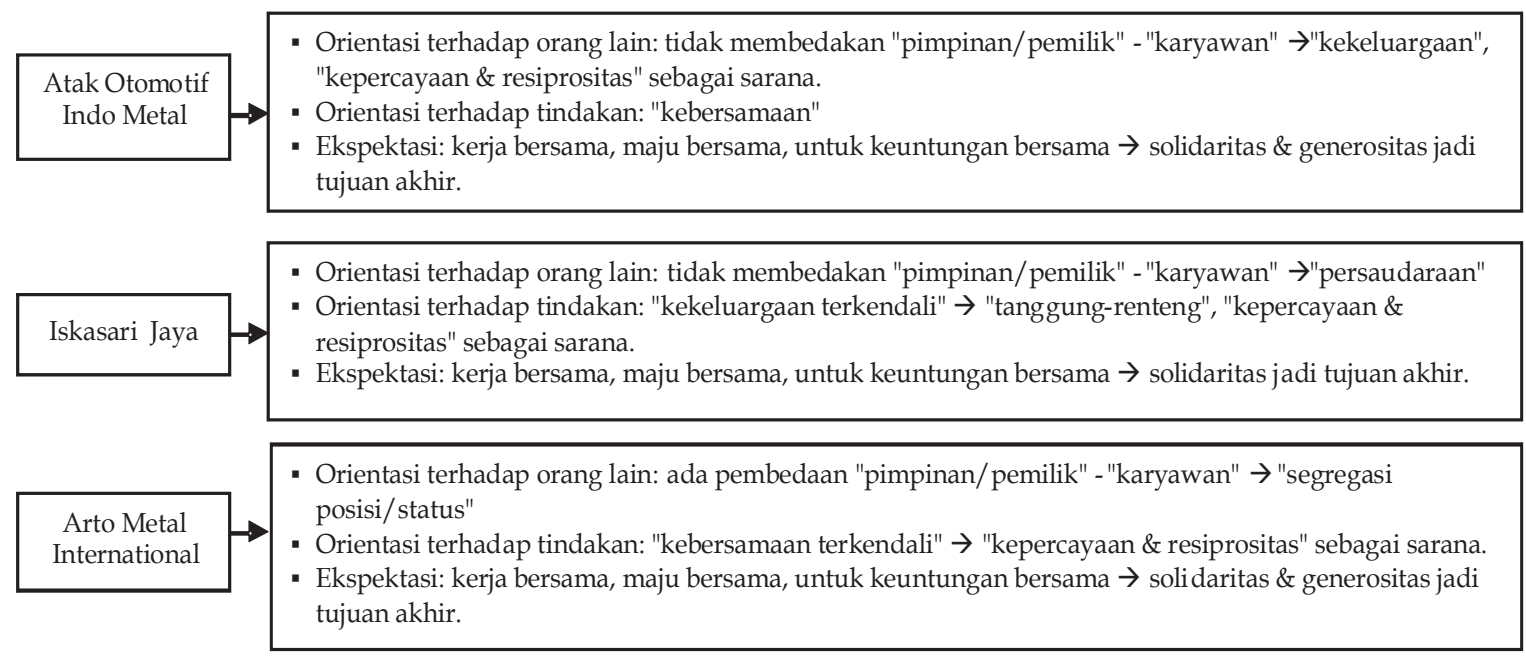

Sumber: Direkonstruksi dari rekaman WN.

\section{Gambar 5. Kemiripan Kognisi Modal Sosial Perusahaan Pelopor SILOW}


membangun modal sosial. Memang ada sedikit perbedaan persepsi mereka tentang kebersamaan, kekeluargaan, dan hubungan dengan staf/karyawan dalam kognisinya modal sosial.

Perbedaan persepsi di atas diduga bersumber dari perbedaan persepsi atau asumsi dasar masing-masing pengusaha di dalam memaknai kata kunci kepercayaan atau trust. Memang, selama ini kepercayaan (trust) diyakini menjadi itu, dari Humphrey \& Schmitz (1998) mengidentifikasi ada dua tipe kepercayaan dalam hal hubungan antara dua orang (interpersonal relations): (a) ascribed trust, dan (b) earned trust. Ascribed trust, atau kepercayaan atas dasar anggapan bahwa orang lain dapat dipercaya, apakah karena ia pernah berhubungan dengannya (direct ascribed trust), atau ia pernah dengar dari orang lain bahwa si A bisa dipercaya (indirect
Ability, atau cognitive, atau competence trust, adalah kepercayaan yang didasarkan atas asumsi bahwa orang lain bisa diandalkan dan diharapkan (reliable and dependable). Seseorang percaya bahwa orang lain akan melakukan apa yang diharapkan, dan memenuhi kewajibannya. Integrity trust, adalah kepercayaan didasarkan atas asumsi bahwa orang lain akan secara konsisten setia terhadap prinsip-prinsip yang dianut oleh si pemberi kepercayaan. Sementara nikasi yang baik sebagai sarana untuk membangun kerjasama dalam tim, yang pada gilirannya memperkuat keberadaan dan peran modal sosial.

\section{Modal Sosial dalam Perspektif ASPILOW}

Secara struktural maupun kognitif, ketiga perusahaan sejak awal memiliki aspirasi dan komitmen yang sama untuk: (a) memajukan SILOW lewat layanan penggunaan teknologi 


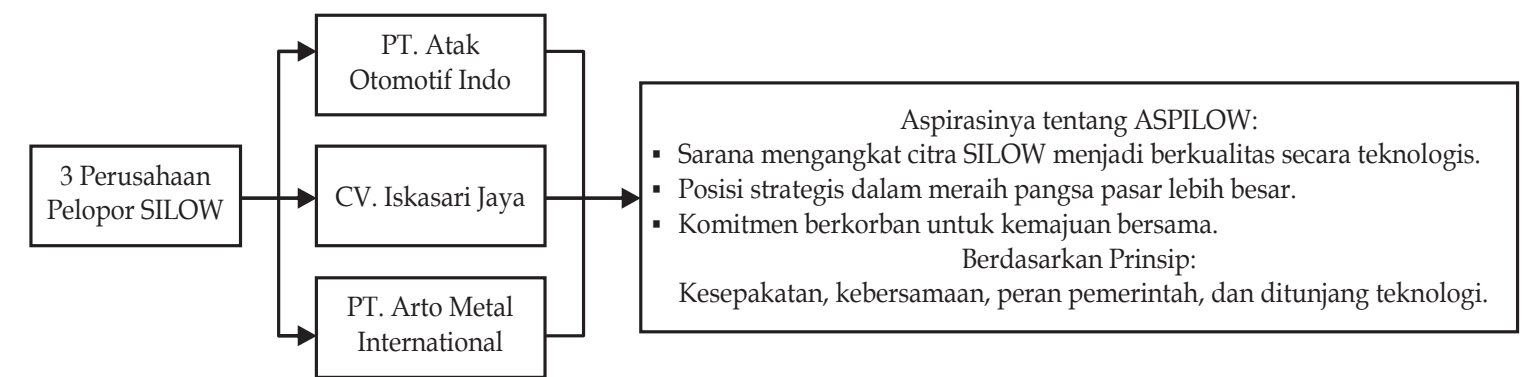

Sumber: Direkonstruksi dari rekaman WN.

Gambar 6. Modal Sosial 3 Perusahaan Pelopor dalam Mendukung ASPILOW

canggih, (b) menempatkan ASPILOW sebagai posisi strategis untuk meraih pangsa pasar lebih besar, dan (c) berkorban demi kemajuan bersama. Komitmen ini diartikulasikan seperti tampak dalam Gambar 6.

\section{Transformasi Ekonomi Modal Sosial dalam Perkembangan SILOW}

Kapasitas transformasi ekonomi modal sosial yang dipersepsi signifikan oleh pelaku sejarah dan pelaku usaha, jika dispesifikasikan menurut batasan Robison et al. (2000, 7-13) bisa dipilah ke dalam: (1) sumbernya, yaitu tindakan kolektif dan jaringan/koneksi, dan (2) peman- faatannya, yaitu transformasi ekonomis dalam tiap fase, lihat Tabel 2.

\section{Rekonstruksi Modal Sosial dalam Dinamika Perkembangan SILOW}

Keberadaan dan peran modal sosial dalam dinamika perkembangan SILOW dapat disintesakan lebih lanjut secara komprehensif dengan menganalisis kecenderungan orientasi perubahan yang terjadi, baik menurut perspektif komunitas, menurut perspektif tiga perusahaan pelopor, maupun menurut persepsi terhadap keberadaan ASPILOW.

Tabel 2. Transformasi Ekonomi Modal Sosial

\begin{tabular}{|c|c|c|c|c|c|}
\hline \multirow{2}{*}{$\begin{array}{c}\text { Sumber } \\
\text { Keberadaan } \\
\text { \& Peran } \\
\text { Modal Sosial }\end{array}$} & \multicolumn{5}{|c|}{ Transformasi Ekonomi Modal Sosial dalam Dinamika Perkembangan SILOW } \\
\hline & $\begin{array}{c}\text { Fase } 1 \\
\text { RSPBW }\end{array}$ & $\begin{array}{l}\text { Fase } 2 \\
\text { SPBW }\end{array}$ & $\begin{array}{l}\text { Fase } 3 \\
\text { SILOW }\end{array}$ & $\begin{array}{c}\text { Fase } 4 \\
\text { SILOW-Sinergi I }\end{array}$ & $\begin{array}{c}\text { Fase } 5 \\
\text { SILOW-Sinergi II } \\
\end{array}$ \\
\hline $\begin{array}{l}\text { 1. Tindakan } \\
\text { kolektif }\end{array}$ & $\begin{array}{l}\text { - Peningkatan status } \\
\text { ekonomi (dari } \\
\text { buruh tani ke } \\
\text { tukang pande) } \\
\text { - Akumulasi modal } \\
\text { ekonomi \& } \\
\text { pengaruh (3 } \\
\text { serangkai) }\end{array}$ & $\begin{array}{l}\text { - Pengadaan bahan } \\
\text { baku "besi tua" } \\
\text { dari PT. DOK } \\
\text { lewat KOPANDE } \\
\text { - Pendirian KWBP } \\
\text { \& pengadaan } \\
\text { bahan baku besi } \\
\text { beton dari PT. KS }\end{array}$ & $\begin{array}{l}\text { - Pengadaan bahan } \\
\text { baku besi plat } \\
\text { dari PT. Krakatau } \\
\text { Steel }\end{array}$ & $\begin{array}{l}\text { - Peningkatan akses } \\
\text { pasar untuk support- } \\
\text { ing industry lewat } \\
\text { ASPILOW }\end{array}$ & $\begin{array}{l}\text { - Peningkatan akses } \\
\text { sumber daya per- } \\
\text { modalan \& pela- } \\
\text { yanan teknologi } \\
\text { produksi lewat } \\
\text { ASPILOW \& LPB- } \\
\text { WA } \\
\text { - Sharing order lintas } \\
\text { anggota ASPILOW }\end{array}$ \\
\hline $\begin{array}{l}\text { 2. Jaringan/ } \\
\text { Koneksi }\end{array}$ & $\begin{array}{l}\text { - Perluasan pasar } \\
\text { lewat PPII }\end{array}$ & $\begin{array}{l}\text { - Redistribusi kele- } \\
\text { bihan bahan baku } \\
\text { ke sentra lain } \\
\text { (Malang \& } \\
\text { Jateng) }\end{array}$ & $\begin{array}{l}\text { - Pembangunan } \\
\text { Gedung Kantor \& } \\
\text { Toko KWBP } \\
\text { lewat PUSKUD, } \\
\text { BUKOPIN }\end{array}$ & $\begin{array}{l}\text { - Efisiensi pengadaan } \\
\text { informasi, pelatihan, } \\
\text { dan akses permodal- } \\
\text { an bersama ITS, } \\
\text { YDBA, \& KWBP } \\
\text { - Sub-kon dengan PT: } \\
\text { Ionuda, SCFM, Indo- } \\
\text { spring, Yamindo, } \\
\text { Schneider }\end{array}$ & $\begin{array}{l}\text { - Akses sumber daya } \\
\text { peralatan produksi } \\
\text { lewat SENADA } \\
\text { - Akses sumber daya } \\
\text { investasi Dies Cen- } \\
\text { ter lewat jonit ven- } \\
\text { ture PT. DMN } \\
\text { (ASPILOW \& Pem- } \\
\text { kab Sidoarjo) }\end{array}$ \\
\hline
\end{tabular}

Sumber: Diolah dari rekaman WN. 


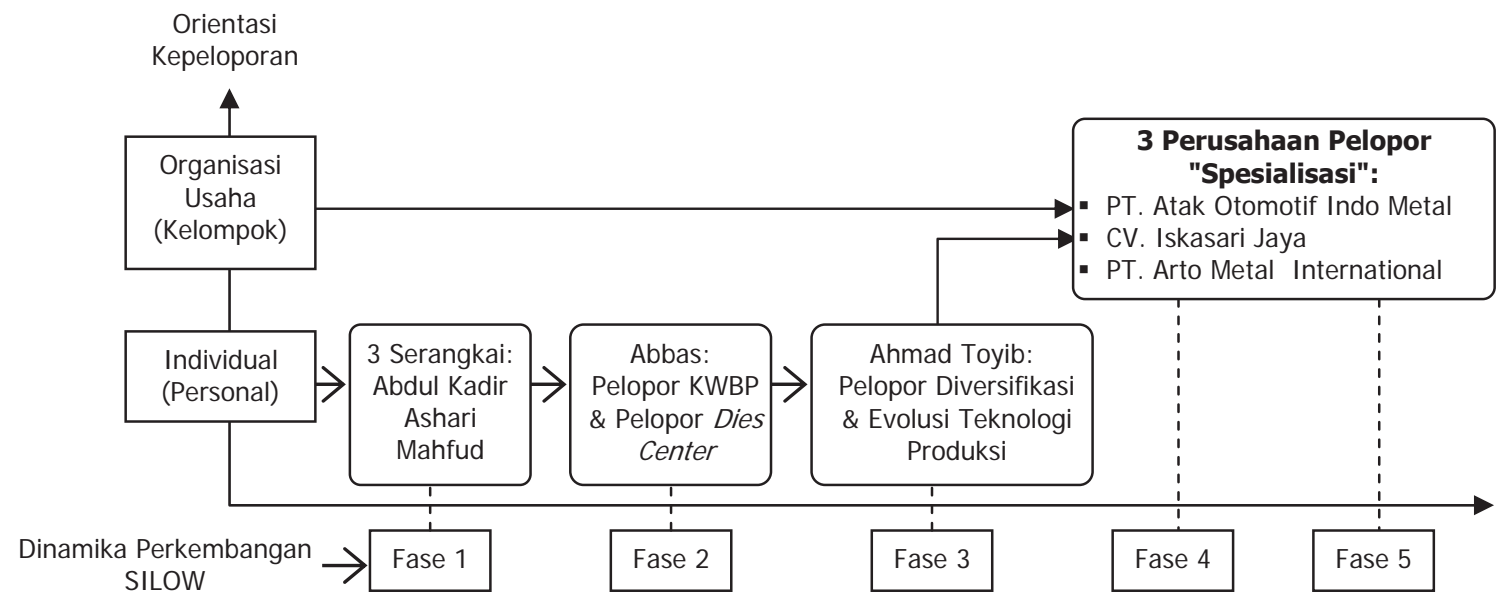

Sumber: Direkonstruksi dari rekaman WN.

Gambar 7. Orientasi Kepeloporan Modal Sosial dalam Dinamika Perkembangan SILOW

\section{Orientasi Kepeloporan dalam Perspektif Komunitas SILOW}

Orientasi Struktural dan Kognitif Modal Sosial dalam Perspektif ASPILOW

\section{Orientasi Kognisi Modal Sosial dalam Perspektif Perusahaan Pelopor}

Kognisi modal sosial yang dibangun oleh tiga perusahaan pelopor memiliki orientasi sama, walaupun berbeda di dalam formulasinya. Seperti sintesis pada Gambar 5, terdapat kesamaan orientasi kognisi tentang ekspektasi untuk kerja bersama, untung bersama, dan solidaritas menjadi tujuan akhir.

\section{Fenomena Penting dalam Dinamika Perkembangan SILOW}

Ada tiga fenomena penting yang patut dibahas berdasarkan analisis dan sintesis rekonstruksi dinamika perkembangan SILOW. Fenomena pertama tentang peran figur (sosok) yang menjadi pelopor dalam setiap fase perkembangan sentra. Fenomena kedua mengenai peran pemerintah di dalam memberdayakan sentra. Fenomena ketiga berhubungan dengan sinergi antara sentra dengan swasta, perguruan tinggi, dan 


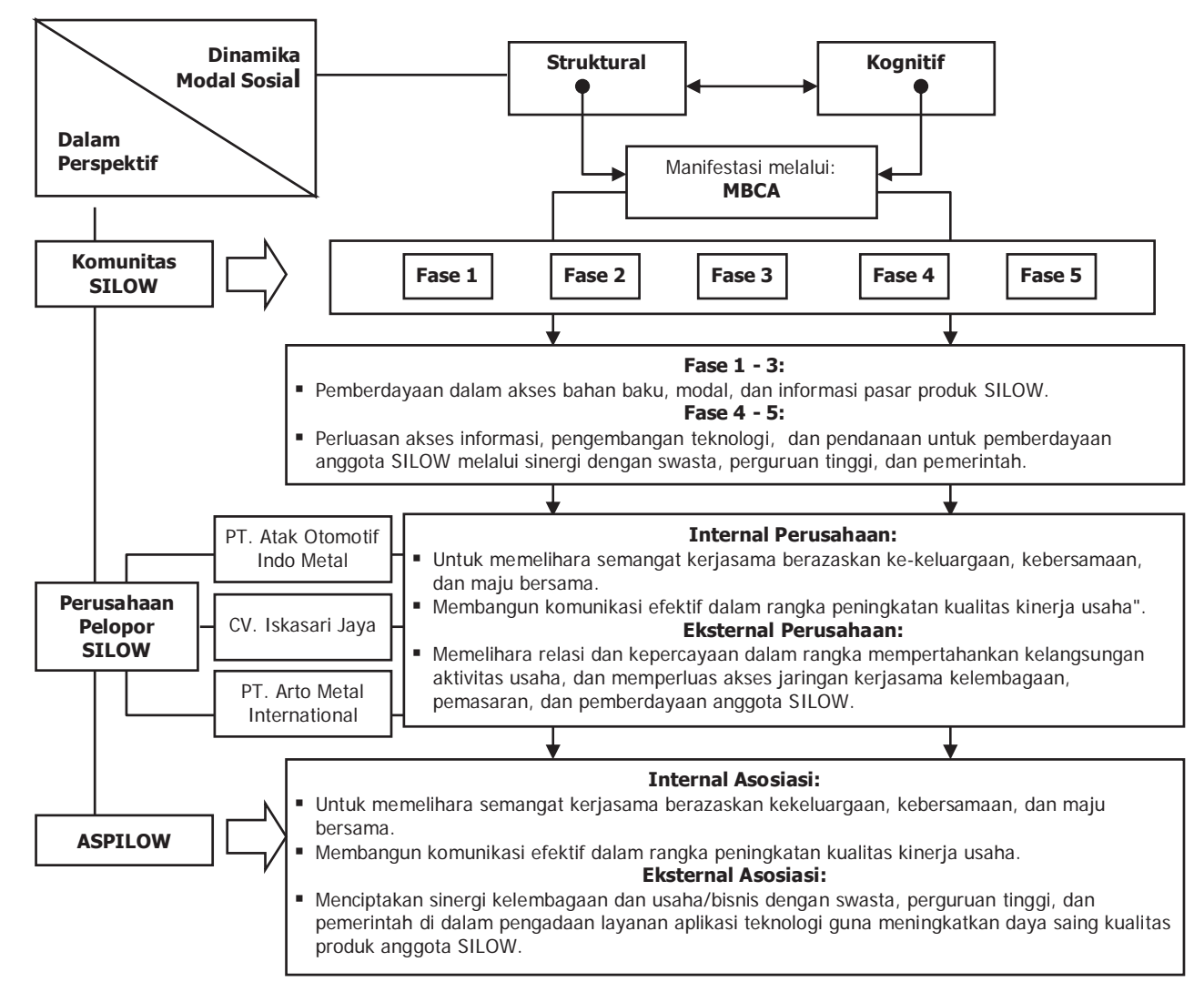

Sumber: Direkonstruksi dari rekaman WN.

Gambar 8. Keberadaan \& Peran Modal Sosial dalam Dinamika Perkembangan SILOW

pemerintah setempat dalam konteks ASPILOW.

\section{Peran Strategis Tokoh Pelopor dalam Perspektif Komunitas SILOW}

Dinamika perkembangan SILOW dalam perspektif komunitas seperti yang dipaparkan sintesisnya dalam Lampiran B (Peta Dinamika Perkembangan SILOW), tidak lepas dari peran dan pengaruh figur yang menjadi pelopornya. Fenomena kepeloporan itu ternyata juga terjadi pada sentra lain, seperti contoh kajian empiris yang telah dilakukan oleh Ariana dkk. (2005) dan Handayani (2001). Kepeloporan pak Iskak dalam merintis dan mengembangkan sentra kerajinan perak di Lumajang (Ariana $d k k$., 2006), mirip dengan kepeloporan AK, ABAS, dan AT dalam kasus penelitian ini. Khusus AK dan ABAS, perannya sama dengan yang dimaksud tokoh/pemuka masyarakat dalam kajian Handayani (2001). Dalam kaitannya dengan keberadaan dan peran modal sosial, kepeloporan AK,
ABAS, dan AT bila dicermati lebih lanjut mirip dengan fenomena spin-offs yang terjadi pada pertumbuhan klaster industri mesin pengepakan (Packaging Machinery Cluster), atau Lembah Pengepakan (Packaging Valley) di Bologna, Italia, yaitu lahirnya unit-unit usaha industri baru di sektor yang sama yang didirikan oleh mantan pekerja perusahaan ACMA (Baldoni \& Patrucco, 2001; dan Boari, 2001). Bedanya, kalau di Bologna dipicu oleh keadaan pasca PD II (pekerja yang terkena PHK mendirikan usaha sendiri pada bidang yang sama), di SILOW dipicu oleh perkembangan permintaan akan barang-barang dari logam (mulai dari perangkat peralatan, perkakas, atau perlengkapan rumah tangga dan kantor, komponen otomotif, hingga komponen infra struktur PLN dan Telkom). Kemiripannya, pengusaha baru (mantan pekerja) di dalam mendirikan usahanya didorong oleh semangat kewirausahaan (entrepreneurship) yang tinggi, latar pengalaman dan keterampilannya dalam industri yang 
sama, umumnya muda usia, dan penuh dengan gagasan bagaimana mengoptimalkan fasilitas manufaktur yang terpasang untuk mendukung pengembangan produk baru. Kemiripan lain yang terkait dengan keberadaan dan peran modal sosial, adalah bahwa meskipun statusnya secara formal sudah berpisah antara pengusaha baru dengan pengusaha semula (tempat dahulu bekerja), namun secara praktis hubungan interpersonal tetap terpelihara dan berkembang. Indikasinya antara lain unit usaha yang baru berdiri mendapat dukungan teknis dan akses pasar dari unit usaha yang lama (Boari, 2001: 67; dan JICA, 2001: 55-56).

Keunikan peran strategis kepeloporan AK, dan AT dalam pengembangan komunitas SILOW adalah bahwa mereka di dalam memajukan usaha menggunakan dua norma yang saling mendukung: (1) niat baik (goodwill, atau sympathy, dalam istilah Adler \& Kwon, 2002, dan Robison et al., 2000), dan (2) keimanan (faith), sebagai landasan untuk bertindak. Bekerja untuk ibadah (dalam agama Islam), bukan semata-mata untuk memenuhi kebutuhan ekonomi, saat ini menjadi bahan diskusi penting, misalnya dalam tema "Faith as Social Capital" yang dikemas oleh Joseph Rowntree Foundation (Eds. R. Furbey, et al.,2006). Kepeloporan AK mengubah pola hidup para petani yang suka minum dan tandakan menjadi muslim yang taat, sekaligus mengubah status buruh tani menjadi tukang pande, menjadi contoh konkrit bagaimana kepeloporan memiliki peran strategis yang kelak mengubah wajah dan masa depan SILOW. Walaupun dengan cara berbeda dari pendahulunya (ayahnya), kedua anak AK: AT dan ABAS, juga memiliki posisi dan peran strategis. Seperti yang telah dipaparkan Fase 2 dan 3 moran $A T$ lohih fokic nada ofinluci rian koperasi industri yang menaungi dan memperkuat kemampuan akses (bahan baku, permodalan, dan pemasaran) para pengusaha logam di SILOW. ABAS memiliki kelebihan dibanding AK dan AT dalam hal melobi dan menggunakan koneksinya untuk kepentingan penguatan KWBP, dan dari UD. Sabaru yang ia miliki, berperan pula dalam mendorong spinoffs berdirinya CV. Atak, CV. Iskasari Jaya, dan CV. Arto Metal.

Kepeloporan secara individual tiga perusahaan pada Fase 4 dan 5 juga memberi sumbangan signifikan dalam hal membangun modal sosial di kalangan SILOW. Komitmen untuk memberdayakan SILOW melalui penggunaan teknologi canggih (dies center), akses jaringan pemasaran dengan perusahaan yang lebih besar (swasta nasional maupun internasional), dan pemerintah (pusat maupun daerah), yang kemudian diwadahi dalam ASPILOW, adalah contoh konkrit dari salah satu propeti keberadaan dan peran modal sosial yang dimaksud Robison et al. (2000) dengan kapasitas transformasi. Kepeloporan tiga perusahaan (PT. Atak Otomotif Indo Metal, CV. Iskasari Jaya, dan PT. Arto Metal International) di dalam membangun modal sosial di kalangan karyawan/staf-nya, memiliki kesamaan dengan pendahulunya (AK, AT, dan ABAS), yaitu mengintegrasikan dua norma: (a) niat baik (goodwill) dan simpati (sympathy) dengan (b) ibadah (faith). Kekhasan masingmasing di dalam mengimplementasikan dan memanifestasikan modal sosial untuk membangun usahanya memang berbeda, tetapi dalam hal komitmen mereka sama.

\section{Peran Pemerintah dalam Fase Perkembang- an SILOW}


untuk mendukung proyek transmigrasi nasional. Peristiwa G-30-S PKI tahun 1965 membuat KOPANDE bubar. Memasuki Fase 3, peran pemerintah kembali efektif melalui kaderisasi perintis ABAS. Pemerintah melalui Kantor Cabang Dinas Perindustrian sejak 1968 mengkader ABAS untuk menjadi perintis (pionir/pelopor) dalam gerakan koperasi (yang sempat terhenti ketika KOPANDE bubar). Dalam mengkader ABAS, pemerintah menggunakan pendekatan tidak langsung dengan cara menanamkan kesadaran pentingnya kerjasama (kooperatif) di kalangan pengusaha pande besi agar tercipta apa yang menurut Jonatan (Kepala Cabang Kantor Dinas Perindustrian waktu itu) multiplier effect. Kaderisasi dilakukan secara bertahap, mulai dari secara perseorangan ABAS diberi penyadaran, hingga ABAS diminta untuk mengajak teman sesama pengusaha yang relatif sepaham (mereka yang pernah menjadi peserta Diklat yang dilaksanakan oleh Depar-

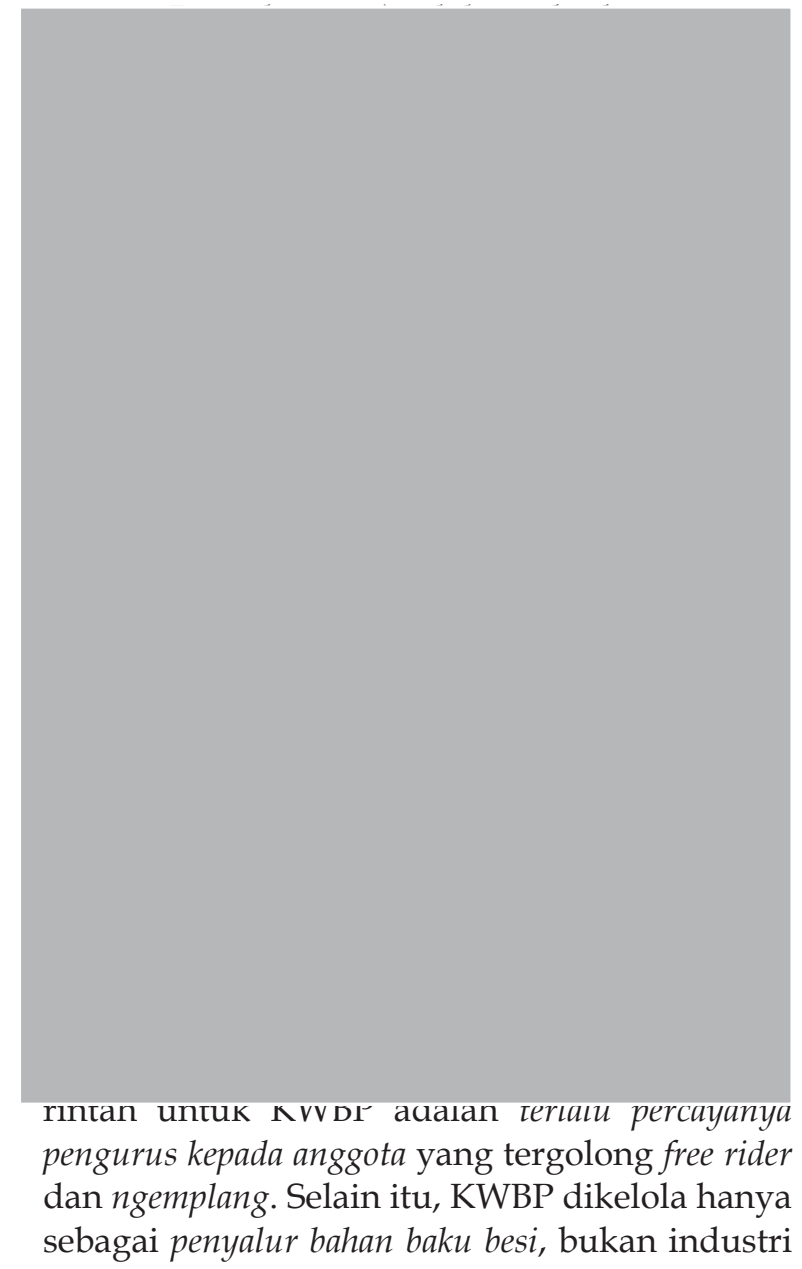

pengolahan, sehingga dengan tiadanya manajemen distribusi yang efektif dan efisien, KWBP dalam kurun waktu itu hanya berurusan dengan menagih utang anggotanya. Pada masa transisi dari Fase 3 ke Fase 4, sekali lagi pemerintah melakukan intervensi melalui pembenahan KWBP, dengan mengusulkan dilakukannya RAT (Rapat Anggota Tahunan). Intervensi ini dilakukan oleh Kepala Kantor Depertemen Koperasi Wilayah Jawa Timur sebenarnya atas inisiatif ABAS dalam rangka reformasi kepengurusan dan pengelolaan KWBP. Dalam RAT terpilih secara aklamasi ABAS sebagai Ketua Pengurus untuk periode 1988 - 1989. Yang menarik untuk dicatat adalah bahwa sebelum RAT, KWBP ternyata hanya namanya koperasi, tetapi praktiknya tidak melaksanakan fungsi-fungsi dasar suatu gerakan yang berbadan hukum koperasi. Baru, pada masa kepengurusan ABAS, fungsi dan prinsip koperasi diterapkan secara penuh. Menurut ABAS, bisa dimaklumi karena pada waktu itu fokusnya pada bagaimana bisa membantu pemenuhan kebutuhan bahan baku besi untuk para anggotanya, bukan pada mengurus badan hukum koperasi. ABAS bersama pengurus yang lain baru secara serius dan berkelanjutan belajar mengurus koperasi di bawah bimbingan dan arahan Departemen Koperasi. Dalam fase transisi itu, peran ABAS kembali menjadi sentral, yaitu melakukan lobi ke pemerintah pusat atas dukungan pengurus yang lain agar kembali mendapat fasilitas memperoleh besi dari PT. KS yang semakin dibutuhkan anggota koperasi. Keberhasilan ABAS dalam melobi seperti yang dipaparkan di muka pada dasarnya salah satu wujud dari apa yang disebut Ronald Burt (2000/2001) structural holes, yang diidentifikasi sebagai brokerage dalam posisinya ABAS memperoleh dan memanfaatkan informasi, koneksi, dan jaringan berbagai sumberdaya untuk merealisasikan apa yang ia inginkan demi KWBP, hasilnya, pada tahun 1989 KWBP menerima anugerah Upakarti Kepeloporan. Dalam hal ini cara kaderisasi perintis terbukti efektif. Peran pemerintah dalam Fase 4 melalui kebijakan Deperrin pada tahun 1994 berupa pendirian UIUKK (Unit Informasi Usaha Kecil dan Koperasi) yang ditempatkan di tiap sentra industri, termasuk SILOW. Tetapi peran ini hanya sebatas penyediaan akses informasi yang dibutuh- 
kan sentra di dalam konsultasi pengembangan usaha, pemasaran, dan jalur penyediaan permodalan. UIUKK baru efektif sebagai lembaga yang memiliki kapasitas akses dan penyediaan dana dan bantuan teknis setelah di dalamnya

\section{Sinergi Triple Helix dalam ASPILOW}

Fenomena sinergi yang berlangsung selama Fase 4 dan 5 menjadi salah satu pemicu kelahiran ASPILOW. Sinergi yang melibatkan SILOW, LPPM-ITS/LPB-AW, dan Pemkab Si- sebagai ancangan untuk mengembangkan SILOW menjadi suatu klaster yang dinamis belum berhasil hingga proyek berakhir, banyak pengetahuan dan pengalaman yang dipetik selama pembelajaran dalam proyek tersebut berlangsung, yaitu timbulnya kesadaran betapa pentingnya melakukan tindakan kolektif yang sinergis untuk memajukan SILOW. Dalam Fase 5, pemerintah daerah (Pemkab Sidoarjo) mulai berperan aktif mendukung ASPILOW dengan share-nya 75 persen pada PT. DMN (Delta Mandiri Nugraha), meskipun inisiatif kemitraan itu berasal dari ASPILOW, bukan dari Pemkab Sidoarjo. ${ }^{7}$

7 Kebijakan pengembangan sentra UKM menjadi klaster dinamis masih memerlukan berbagai kajian tentang, misalnya: "Faktor-faktor yang mempengaruhi perkembangan sentra UKM menjadi klaster dinamis" (Choirul Djamhari, dalam Infokop, No. 29 Th. XXII, 2006); "Apakah fenomena klaster dinamis mampu memberikan efek 'vibrant' dan 'growth rate cycles' bagi industri-industri terkait disekitarnya?" (A.T.H. Kuah dalam Cluster Theory and Practice: Advantages for the Small Business Locating in a Vibrant Cluster. Journal of Research in Marketing and Entrepreneurship, Vol. 4, Issue 3, 2002, pp. 206-228); dan "Bagaimana mengembangkan modal sosial di antara pelaku usaha, upgrading teknologi, dan networking pasar internasional dalam lingkungan sentra?"

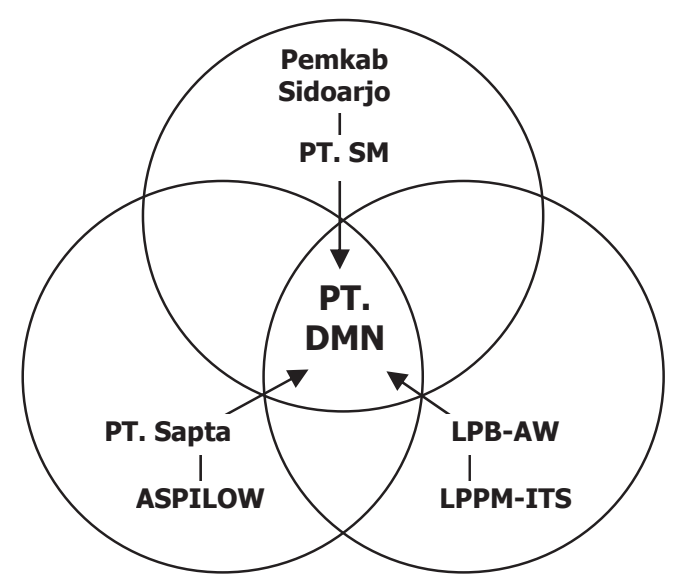

Gambar 9. PT. DMN sebagai Hibrida Organisasi dalam Triple Helix

Dalam batas tertentu triple helix bisa diformulasi seperti bentuk kajian dan bantuan teknis yang diberikan LPPM-ITS ketika PT. Atak Otomotif Indo Metal menghadapi masalah teknologi pengerasan plat baja (lihat penuturan pengelola LPB-Astra Waru dalam KOMPAS-Cybermedia, 2 April 2004).

(Kacung Marijan, dalam INSAN, Vol. 7, No. 3, Desember 2005). 


\section{Reposisi Keberadaan dan Peran Modal Sosial}

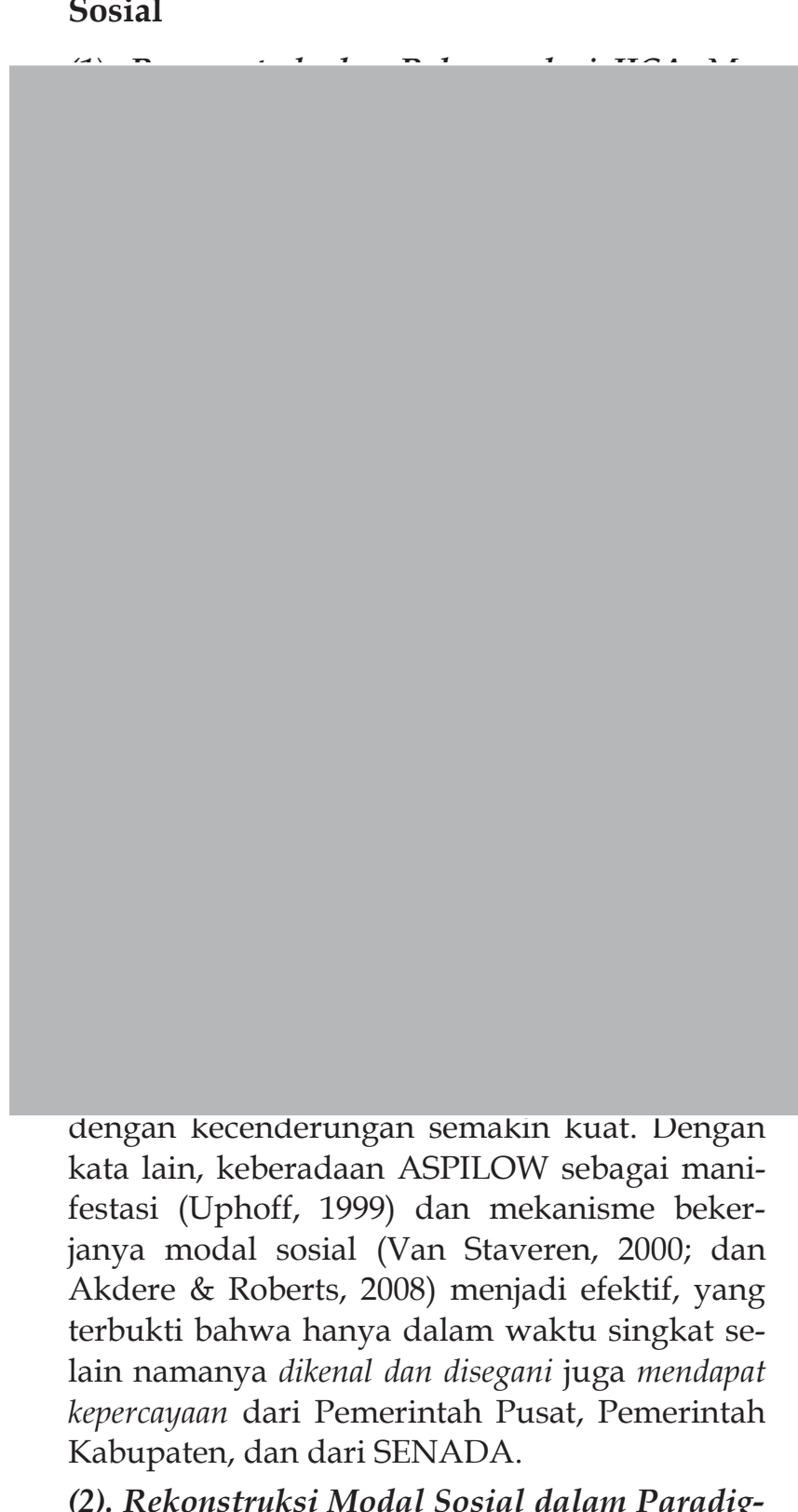

ma EKB. Keberadaan dan peran modal sosial dalam paradigma EKB (Ekonomi Kelembagaan Baru) diposisikan sebagai anak cabang dari ekonomi sosial baru dan ekonomi biaya transaksi (Gambar 1). Jika dikaitkan dengan teori tindakan kolektif (MBCA) dari Krishna \& Uphoff (1999) dan Uphoff (1999), modal sosial juga menjadi anak cabang teori tindakan kolektif. Modal sosial menjadi sumber sekaligus konsekuensi atas tindakan kolektif. Dalam lingkup kebijakan pengembangan sentra menuju klaster dinamis, Schmitz (1999) (walaupun tidak menyinggung teori MBCA-nya Uphoff), mengajukan teori efisiensi kolektif (collective efficiency) dalam rangka meniawab mengapa dan bagaimana sentra in-

8 Kasus yang dijadikan kajian: sentra industri sepatu di "Sinos Valley" Brasil Selatan dan sentra industri peralatan operasi bedah di Sialkot, Punjab, Pakistan. Konsep dan teori yang ia ajukan terinspirasi dari studi yang sebelumnya dilakukan oleh Khalid Nadvi, Small Firm Industrial Districts in Pakistan. Doctoral Thesis, Institute of Development Studies, University of Sussex, 1996.

9 Kajian serupa dilanjutkan oleh Rasmus Lema dalam The Role of Collective Efficiency in Bangalore's Software-export Success. Paper disajikan dalam DRUID Academy Winter Conference "Industrial Evolution and Dynamics." Skorping, Denmark: January 27-29, 2005.

10 Didukung pula pernyataan Halpern: "Societies are not composed atomized individuals. People are connected with one another through intermediate social structures webs of association and shared understabdings of how to behave. This social fabric greatly affects with whom, and how, we interact and co-operate. It is this everyday fabric of connection and tacit cooperation that the concept of social capital is intended to capture." (David Halpern, Social Capital, Polity Press, Cambridge, UK., 2005, hal. $3)$. 


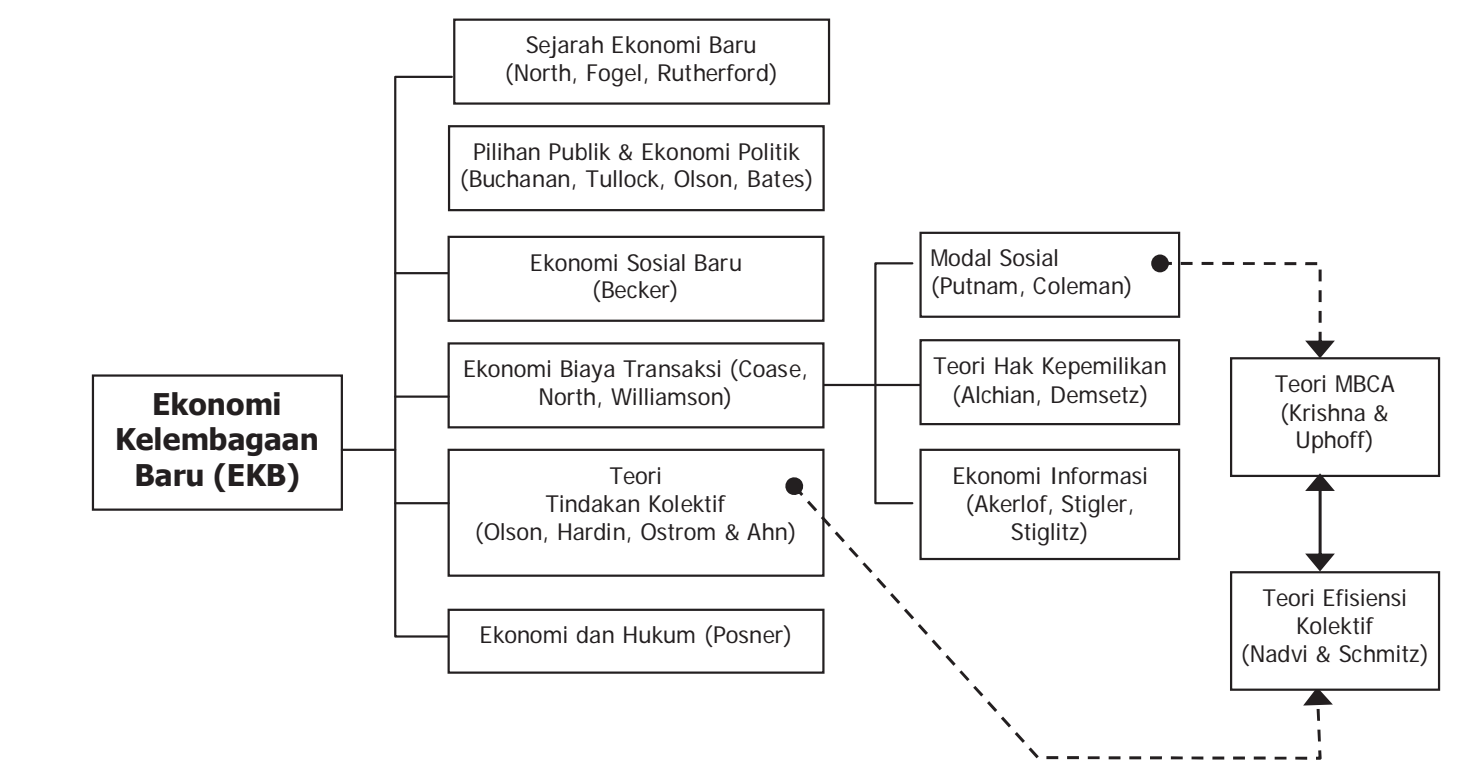

Sumber: Elaborasi peneliti dari Kheralah \& Kirsten (2001/2002), Krishna \& Uphoff (1999), Uphoff (1999), Schmitz \& Nadvi (1999), dan Ostrom \& Ahn (2007)

\section{Gambar 10. Rekonstruksi Posisi Modal Sosial dalam Paradigma EKB}

Kalimat terakhir dari kutipan di atas secara tepat menggambarkan situasi dan kondisi yang melatarbelakangi kelahiran ASPILOW, sehingga layak jika MBCA dan efisiensi kolektif menjadi refleksi dari teori tindakan kolektif generasi kedua. Teori dan kajian empiris dari MBCA (Krishna \& Uphoff) dan Efisiensi Kolektif (Nadvi \& Schmitz) jika dielaborasikan ke dalam paradigma EKB secara konseptual dan teoritis tampak dalam Gambar 10.

Keberadaan dan peran modal sosial dalam dinamika perkembangan SILOW juga memenuhi dua wilayah operasi EKB: (a) lingkungan kelembagaan (institutional environment), atau level makro, dan (b) pengaturan kelembagaan (institutional arrangement/ government), atau level mikro. ${ }^{11}$ Sejak Fase 1 hingga Fase 5, keberadaan dan peran modal sosial selalu terwujud dalam bentuk lembaga yang mengatur kegiatan produksi, pertukaran, dan distribusi, yang semuanya mengarah pada kesepakatan antarunit usaha (pelaku usaha) di SILOW melalui berba-

11 Lihat uraian singkatnya dalam Yustika (2006: 58), atau lebih lengkap Peter G. Klein, New Institutional Economics. Dalam Encyclopedia of Law and Economics, B. Bouckearet \& G.D. Geest, (Eds.). Edward Elgar and University of Ghent, hal. 456-489. gai cara agar kerjasama dapat berlangsung dan bertahan hingga mencapai puncaknya dengan terbentuknya ASPILOW.

\section{SIMPULAN}

Secara kronologis dan konfiguratif dinamika perkembangan SILOW sejak pande besi hingga ASPILOW dapat dipetakan ke dalam lima fase, masing-masing memiliki latar dan karakteristik berbeda: (1) Rintisan Sentra Pande Besi (19391950), (2) Sentra Pande Besi Waru (1950-1977), (3) Sentra Industri Logam Waru (SILOW) (19781994), (4) SILOW-Sinergi I (1994-2006), dan (5) SILOW-Sinergi II (Mulai 2006). Keberadaan dan peran modal sosial secara struktural dan kognitif dalam dinamika perkembangan SILOW dapat dipilah ke dalam tiga perspektif yang berbeda: (1) komunitas SILOW, (2) perusahaan pelopor pengembangan SILOW, dan (3) ASPILOW. Dalam perspektif komunitas SILOW, pada setiap fase selalu ditandai dengan keberadaan tokoh dan kelembagaan yang menjadi medium bagaimana tokoh tersebut membangun dan mengembangkan modal sosial dalam konteks perkembangan SILOW. Dalam perspektif peru- 
sahaan pelopor, terdapat perbedaan latar historis, bisnis inti yang menjadi andalannya, pendekatan di dalam membangun dan mengembangkan modal sosial di masing-masing perusahaan, dan persepsinya terhadap keberadaan ASPILOW. Dalam perspektif ASPILOW, ketiga perusahaan pelopor yang diteliti memiliki persepsi yang sama dan semangat serta komitmen yang sama untuk memajukan SILOW melalui pendayagunaan teknologi, penyediaan layanan teknis kepada anggota SILOW, dan bersinergi dengan pemerintah serta perguruan tinggi. Rekonstruksi secara konseptual dan teoritis keberadaan dan peran modal sosial dalam dinamika perkembangan SILOW menurut proksi 4 perspektif modal sosial (Woolcock \& Narayan, 1999) dapat disejajarkan bahwa: (1) fase 1 termasuk dalam perspektif komunitarian, (2) fase 2 termasuk dalam perspektif jaringan, (3) fase 3 termasuk dalam perspektif jaringan dan kelembagaan, (4) fase 4 dan 5 termasuk dalam perspektif sinergi. Dengan menggunakan proksi MBCA (Uphoff, 1999) keberadaan dan peran modal sosial semakin produktif dalam fase SILOW-Sinergi I dan II. Dengan demikian, secara umum keberadaan dan peran modal sosial dalam konteks dinamika perkembangan SILOW selama ini sudah memberi sumbangan signifikan, baik dalam perspektif komunitas SILOW, perspektif masing-masing perusahaan pelopor, maupun perpektif ASPILOW.

Dalam konteks ekonomi pembangunan, simpulan dalam paragraf di atas juga memperkuat proposisi yang diartikulasikan Sims (2006) dan Stevens (2005: 10-11) tentang modal sosial sebagai pilar dari bentuk-bentuk modal yang lain (modal fisik, finansial, dan manusia). Dalam konteks yang lebih spesifik, juga memperkuat proposisi we-rationality theory dari Hollis \& Sugden (1993) - yang ditelaah dan direkonstruksi oleh Di Ciaccio (2005) - sebagai ganti orientasi individual rationality teori yang selama ini menjadi asumsi dasar ekonomi neoklasik.

\section{DAFTAR PUSTAKA}

Adam, F., \& Roncevic, B. 2003. Social Capital Recent Debates and Research Trends. So- cial Sciences Information, 42(3): 155-183.

Addler, P.S. \& Kwon, S.W. 2002. Social Capital: Prospects for a New Concept. Academy of Management Review, 27(1): 17-40.

Akdere, M. 2005. Social Capital Theory and Implications for Human Resource Development. Singapore Management Review, 27: 1-24.

Akdere, M. E Roberts, P.B. 2008. Economics of Social Capital: Implications for Organizational Performance. Advances in Developing Human Resources, 10(6): 803-816.

Ariana, L., Kusbiantono \& Setiawan, S. 2006. Pengaruh Modal Sosial dalam Kemandirian Sentra Industri yang Berada di Daerah Pedesaan. Jakarta: LIPI - Pusat Penelitian Perkembangan Iptek.

Baker, W. 1990. Market Networks and Corporate Behavior. American Journal of Sociology, 96: 589-625.

Baker, W. 2000, Achieving Success Through Social Capital. San Franscisco, CA: JoseyBass.

Baker, W. 2001. Building Social Capital as a HR Competence. IHRIM Journal, (April-June 2001): 98-109.

Baldoni, G.L \& Patrucco, P.P. 2001. High Road to Work Organisation Case Study. The Bologna Packaging Machinery Cluster. NOMISMA, September 2001.

Barber, B. 1995. All Economies are 'Embeded': The Career of the Concept and Beyond. Social Research, 62(2): 387-413.

Bauer, M. 1987. The Narrative Interview - Outline and Comments on a Technique for Qualitative Data Collection. Manuscript. LSE, Department of Social Psychology.

Bauer, M. 1991. Resistance to Change: A Monitor of New Technology. System Practice, 4(3): 181-196.

Bauer, M. 1996. The Narrative Interview: Comments on a Technique for Qualitative Data Collection. Papers in Social Research Methods - Qualitative Series No. 1. London: London School of Economics and 
Political Science.

Best, M.H. 1999. Cluster Dynamics in Theory and Practice: Singapore/Johor and Penang Electronics. UNIDO/ISIS.

Boari, C. 2001. Industrial Clusters, Focal Firms, and Economic Dynamism: A Perspective from Italy. World Bank Institute.

Bourdieu, P. 1985. The Forms of Capital. In J.G. Richardson (Ed.), Handbook of Theory and Research for the Sociology of Education. New York: Greewood. Pp. 241-258.

Bourdieu, P. \& Wacquant, L.J.D. 1992. An Invitation to Reflexive Sociology. Chicago: University of Chicago Press.

Burt, R.S. 2000. Structural Holes vs Network Closure as Social Capital. Pre-print for a chapter in Social Capital: Theory and Research. N. Lin, K.S. Cook \& R.S. Burt (Eds.). Aldine de Guyter.

Burt, R.S. 2001. The Social Capital of Structural Holes. Pre-print of a chapter in New Directions in Economic Sociology. Mauro F. Guilen, R. Collins, P. England \& M. Meyer (Eds.). New York: Russell Sage Foundation.

Castells, M. 1996. The Rise of the Network Society. The Information Age: Economy, Society and Culture. Vol. 1. Cambridge. Mass.: Blackwell.

Coleman, J.S. 1990. Foundations of Social Theory. Cambridge, MA: Harvard University Press.

Coleman, J.S. 1988. Social Capital in the Creation of Human Capital. American Journal of Sociology, 94, Supplement: S95-S120.

Dasgupta, P. \& Serageldin, I. (Eds.). 1999. Social Capital: A Multi Faceted Perspective. Washington, DC: The World Bank.

Di Ciaccio, S. 2005. Social Capital: Social Relations and Economic Rationality, Crossroads. 5(1): 43-77.

Djamhari, C. 2006. Faktor-faktor yang Mempengaruhi Perkembangan Sentra UKM menjadi Klaster Dinamis. Infokop, 29: 83-91.
Etzkowitz, H. \& Mello, J. M. C. D. 1994. The Rise of Triple Helix Cluster: Innovation in Brazilian Economic and Social Development. International Journal of Technology and Management $\mathcal{E}$ Sustainable Development, 2(3): 159-171.

Etzkowitz, H. \& Leydesdorff, L. (Eds.). 1997. Universities in the Global Knowledge Economy: A Ttriple Helix of University-industryGovernment Relations. London: Cassell.

Etzkowitz, H. 2002. The Triple Helix of University-Industry-Government Relations: Implications for Policy and Evaluation. Working Paper 2002-11. http://www. sister. nu. Diakses: 27 Juni 2008.

Etzkowitz, H. 2003. Innovation in Innovation: The Triple Helix of University-IndustryGovernment Relations. Social Science Information, 42(3): 293-337.

Etzkowitz, H. 2007. The Triple Helix Model. Power point presentation at the First Annual Triple Helix Summit, February 12-13, 2007. University of Hawaii - East West Center.

Eisenhardt, K, M. 1989. Building Theory from Case Study Research. Academy of Management Review, 14(4): 532-550.

Fine, B. \& Lapavitsas, C. 2004. Social Capital and Capitalist Economies. South Eastern Europe Journal of Economics, 1: 17-34.

Fukuyama, F. 1995. Trust: The Social Virtues and the Creation of Prosperity. New York: Free Press.

Fukuyama, F. 1997. Social Capital and the Modern Capitalist Economy: Creating a High Trust Workplace. Stern Business Magazine, 41(1).

Furbey, R., Dinham, A., Farnell, R., Finneron, D. \& Wilkinson, G. 2006. Faith as Social Capital. Bristol, UK: Joseph Roundtree Foundation.

Granovetter, M. 1985. Economic Action and Social Structure: The Problem of Embeddedness, American Journal of Sociology, 91: 481510. 
Granovetter. 1992. Economics institutions as Social Constructions: A Framework for Analysis. Acta Sociologica, 35: 3-11.

Grootaert, C. \& van Bastelaer, T. 2002. Understanding and Measuring Social Capital: A Synthesis of Findings and Recommendations from the Social Capital Initiative. World Bank: Washington, D.C.

Halpern, D. 2005. Social Capital. Cambridge, UK: Polity Press.

Handayani, W. 2001. Efisiensi Kolektif pada Sentra Industri Mebel Kayu Jepara. Tesis Magister. ITB: Bandung.

Hay, C. 2002. Political Analysis: A Critical Introduction. Basingstoke: Palgrave.

Helfat, C. \& Lieberman, M. 2002. The Birth of Capabilities: Market Entry and the Importance of Prehistory. Industrial and Corporate Change, 11(4): 725-760.

Hollis, M. \& Sugden, R. 1993. Rationality in Action. Mind, New Series, 102(405): 1-35.

Humphrey, J. \& Schmitz, H. 1998. Trust and Interfirm Relations in Developing and Transition Economies. Journal of Development Studies, 34(4): 32-61.

Irawaty, D. 2006. Understanding the Triple Helix Model from the Perspective of the Developing Country: A Demand or A Challenge for Indonesian Case Study? MPRA Working Paper No. 5829.

Irawaty, D. 2007. Strengthening Cluster Building in Developing Country Along-side the Triple Helix: Challenge for Indonesian Clusters - A Case Study of the Java Region. MPRA Working Paper No. 5831.

JICA. (2001). Study on 10 Pilot Industrial Sentra. Vol. 1: Metalworks Sentra. Laporan Survei, Maret 2001.

JICA. 2004a. The Study on Strengthening Capacity of SME Clusters in Indonesia. Final Report Main Report. March 2004.

JICA. 2004b. Studi Penguatan Kapasitas Klaster UKM di Republik Indonesia. Laporan Proyek Percontohan: Langkah-langkah yang
Diambil Menuju Klaster Dinamis. Maret 2004.

JICA. 2004c. The Study on Strengthening Capacity of SME Clusters in Indonesia. Final Report Summary. March 2004.

Johnson, N., Suarez, R. \& Lundy, M. 2002. The Importance of Social Capital in Columbian Rural Agro-enterprises. CAPRi Working Paper, No. 26.

Jovchelovitch, S. \& Bauer, M. 2002/2007. Narrative Interviewing [online]. London: LSE Research Online.

Kherallah, M. \& Kirsten, J. 2001. The New Institutional Economics: Application for Agricultural Policy Research in Developing Countries. MDSS Discussion Paper No. 41. IFRI, Washington D.C. June 2001.

Kherallah, M. \& Kirsten, J. 2002. The New Institutional Economics: Application for Agricultural Policy Research in Developing Countries, Agrekon. 1(2):110-133.

Klein, H.K. \& Myers, M.D. 1999. A Set of Principles for Conducting and Evaluating Interpretive Field Studies in Information Systems. MIS Quarterly, 23(1): 67-94.

Klein, P.G. 1998. New Institutional Economics. Encyclopedia of Law and Economics (B. Bouckearet \& G.D. Geest, eds.). Edward Elgar and University of Ghent. Pp. 456489.

KOMPAS-Cybermedia, 2 April, 2004. Industri Komponen Ngingas Meradang, Tapi Masih Mampu Bertahan.

Krishna, A. \& Uphoff, N. 1999. Mapping and Measuring Social Capital: A Conceptual and Empirical Study of Collective Action for Conserving and Developing Watersheds in Rajasthan, India. Social Capital Initiative Working Paper No. 13. Washington, D.C: World Bank.

Kuah, A.T.H. 2002. Cluster Theory and Practice: Advantages for the Small Business Locating in a Vibrant Cluster. Journal of Research in Marketing and Entrepreneurship, 4(3): 206-228. 
Leydersdoff, L., \& Basselaar, P.V. 1997. Technological Development and Factor Substitution in a Complex Dynamic System. Journal of Social and Evolutionary Systems.

Levin, D.Z., Cross, R. \& Abrams, L.C. 2002. Why Should I Trust You? Predictors of Interpersonal Trust in A Knowledge Transfer Context. Paper Presented at 2002 Academy of Management Meeting, Denver Colorado. August, 19, 2002.

Lewicki, R.J., McAllister,D.J. \& Bies, R.J. 1998. Trust and Distrust: New Relationship and Realities. Academy of Management Review, 23(3): 438-458.

Lin, N. 1999. Building a Network Theory of Social Capital. Connections, 22(1): 28-51.

Maloney, W.G., Smith, G. \& Stoker, G. 2000. Social Capital and Urban Governance: Adding a More Contextualized "TopDown" Perspective. Political Studies, 48: 802-820.

Marijan, K. 2005. Mengembangkan Industri Kecil Menengah melalui Pendekatan Kluster. INSAN, 7(3): 216-225.

Mubyarto. 2000. Membangun Sistem Ekonomi. Yogyakarta: BPFE.

Nadvi, K. 1996. Small Firm Industrial Districts in Pakistan. Doctoral Thesis. Institute of Development Studies, University of Sussex.

Nahapiet, J. \& Ghoshal, S. 1998. Social Capital, Intellectual Capital, and the Organizational Advantage. Academy of Management Review, 23: 242-266.

OECD. 2001. The Well-being of Nations. The Role of Human and Social Capital. Paris: OECD.

Oh, H., Kilduff, M., \& Brass, D.J. 1999. Communal Social Capital, Linking Social Capital, and Economic Outcomes. Paper presented at The Annual Meeting of the Academy of Management. Chicago.

Ostrom, E. 1999. Social Capital: a Fad or a Fundamental Concept? Dalam P. Dasgupta \& I. Serageldin (Eds.), Social Capital: A Multifaceted Perspective. Washington, D.C: The World Bank. Pp. 172-214.
Ostrom, E. \& Ahn, T.K. 2007. The Meaning of Social Capital and Its Link to Collective Action. "Workshop in Political Theory and Policy Analysis. Indiana University." Forthcoming 2008 in Handbook on Social Capital. Gert T. Svendsen \& Gunnar L. Svendsen (Eds.). North Hampton, MA: Edward Elgar.

Perry, C., Christie, M., Rowe, P., \& Chamard, J. 2000. Implementation of Realism in Case Study Research Methodology. http:// www. sbaer.uca.edu/research/icsb/2000/pdf/0 68.pdf). Diakses: 02 Maret 2008.

Polanyi, K. 1944. The Great Transformation: The Political and Economic Origins of Our Time. Boston: Beacon Press.

Porter, M. 1990. The Competitive Advantage of Nations. NewYork: Free Press.

Portes, A. 1998. Social Capital: Its Origins and Applications in Modern Sociology. Annual Review Sociology, 24: 1-24.

Putnam, R.D., Leonardi, R., \& Nanetti, R.Y. 1993. Making Democracy Work: Civic Traditions in Modern Italy. Princeton, NJ: Princeton University Press.

Putnam, R.D. 1995. Bowling Alone: America's Declining Social Capital. Journal of Democracy, 6(1): 65-78.

Quibria, M.G. 2003. The Puzzle of Social Capital. A Critical Review. ERD Working Paper Series No. 40. Asian Development Bank.

Robison, L.J., Schmid, A.A. \& Siles, M.E. 2000. Is Social Capital Really Capital? Paper submitted to the Review of Social Economy. February 2000.

Rosenthal, G. 1993. Reconstruction of Life Stories: Principles of Selection in Generating Stories for Narrative Biographical Interviews. Dalam R. Josselson \& A. Lieblich (Eds.). The Narrative Study of Lives. London: Sage Publications.

Ruuskanen, P. 2004. Social Capital and Innovations in Small and Medium Sized Enterprises. Paper presented at the DRUID Summer Conference. Elsinore, Denmark, 
June 14-16, 2004.

Saiki, S.S.,Jr. \& Jordan, P.J. 2007. The Triple Helix Fundamental. Power point presentation at the First Annual Triple Helix Summit, February 12-13, 2007. University of Hawaii - East West Center.

Scheibelhofer, E. 2005. A Reflection Upon Interpretive Research Techniques: The Problem-Centered Interview as a Method for Biographic Research. Dalam N. Kelly, C. Horrocks, K. Milnes, B. Roberts, \& D. Robinson (Eds.). Narrative, Memory, and Everday Life, Chapter 3, pp. 19-32. University of Huddersfield.

Schmitz, H. 1999. Collective Efficiency and Increasing Returns. Cambridge Journal of Economics, 23: 465-483.

Schmitz, H. \& Loebis, L. 2003. Lessons from the JICA Project 'Strengthening the Capacity of SME Clusters in Indonesia'. Report prepared for KRI International Corp. Tokyo.

Schmitz, H. \& Nadvi, K. 1999. Clusters and Industrialization: An Introduction. World Development, 27(9). Oxford: Pergamon.

Schutze, F. 1977. Die Technick des Narrativen Interviews in Interaktionsfeldstudien dargestellt an einem Projekt zur Erforschung von Kommunikativen Machtstrukturen. Unpublished manuscript. Unversity of Bielefeld, Department of Sociology.

Schutze, F. 1984. Kognitive Figuren des Autobiographischen Stegreiferzählens. Dalam M. Kohli and Robert Günter (Eds.). Biographie und Soziale Wirklichkeit. Neue Beiträge und Forschungsperspektiven. Stuttgart, Germany: Metzler. Pp. 78-117.

Sims, E. 2006. Social Capital in Firms, Alliances \& Clusters: Why It Is Important for Productivity \& Competitiveness; and How to Build It. Dalam Tan Wee-Liang (Ed.). Social Capital in Asia: An Exploratory Study. Tokyo: Asian Productivity Organization (APO). Pp. 39-81.

Stevens, R. 2005. What is Social Capital? How can it be measured? What are the implications of social capital for education? Paper presented to a Conference of the Australian Association of Research in Education. Parramatta, NSW, Wednesday, 30 November 2005.

Tambunan, T. 2005. Promoting Small and Medium Enterprises with a Clustering Approach: A Policy Experience from Indonesia, Journal of Small Business Management, 43(2): 138-154.

Turpin, T., Sullivan, N. \& Deville, A. 1993. Crossing Innovation Boundaries: The Formation and Maintenance of Research Links between Industry and Universities in Australia. AGPS: Canberra.

Uphoff, N. 1999. Understanding Social Capital: Learning from the Analysis and Experience of Participation. Dalam P. Dasgupta \& I. Serageldin (Eds.). Social Capital: A Multifaceted Perspective. Washington, D.C: The World Bank. Pp. 215-249.

Urata, S. 2000. Outline of Tentative Policy Recommendation for SME Promotion in Indonesia. May 17, 2000.

Whittaker, J., Burns, M. \& Van Beveren. 2003. Understanding and Measuring the Effect of Social Capital on Knowledge Transfer within Clusters of Small-Medium Enterprises. 16 $6^{\text {th }}$ Annual Conference of Small Enterprise Association of Australia and New Zealand. 28 September - 1 October 2003.

Woolcock, M. 1998. Social Capital and Economic Development: Toward a Theoretical Synthesis and Policy Framework. Theory and Society, 27: 151-208.

Woolcock, M. \& Narayan, D. 2000. Social Capital: Implications for Development, Theory, Research, and Policy. The World Bank Research Observer. 15(2): 225-249.

Yustika, A.E. 2006. Ekonomi Kelembagaan: Definisi, Teori, \& Strategi. (Edisi Pertama, September 2006). Malang: Bayu Media. 


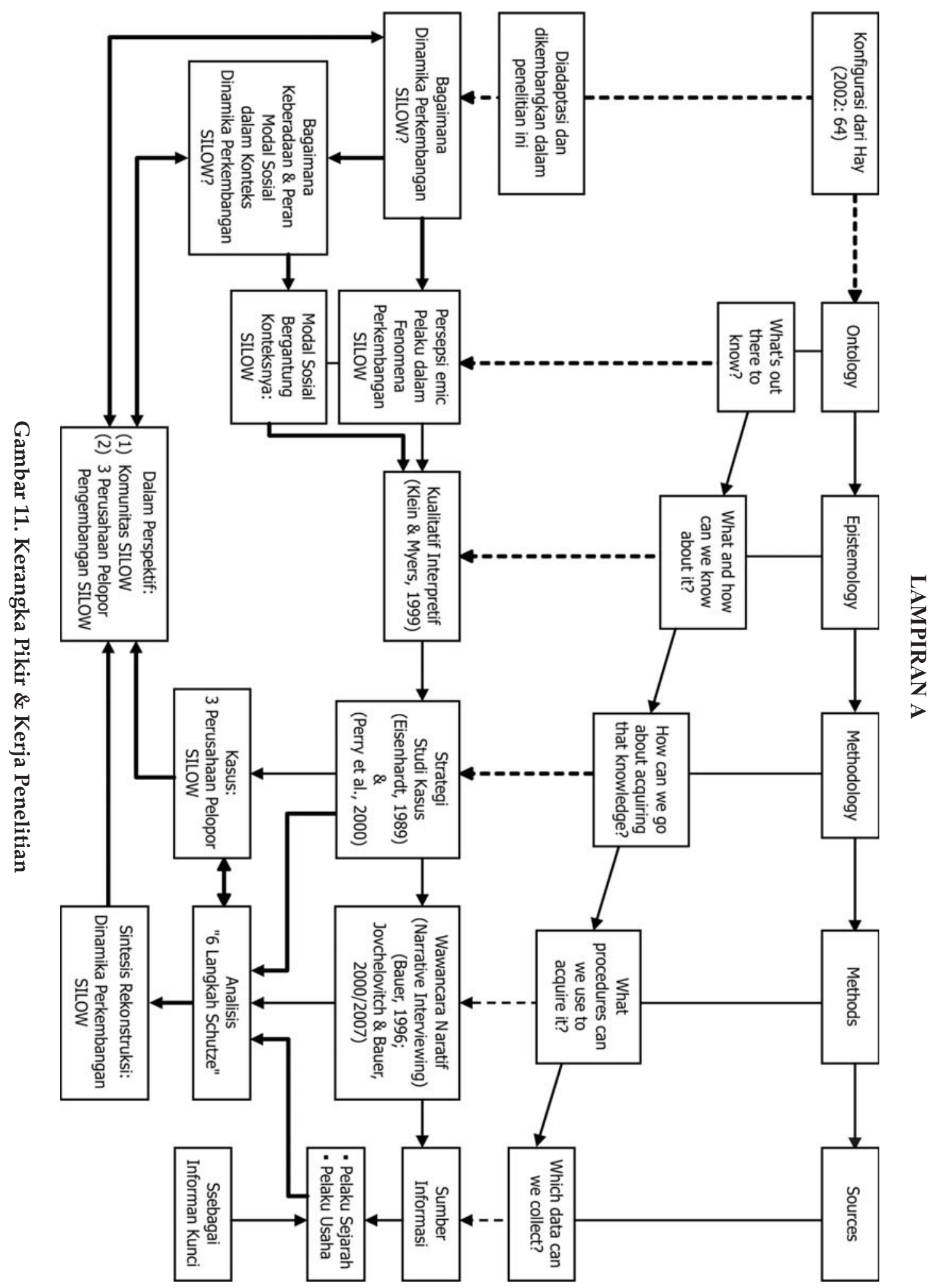




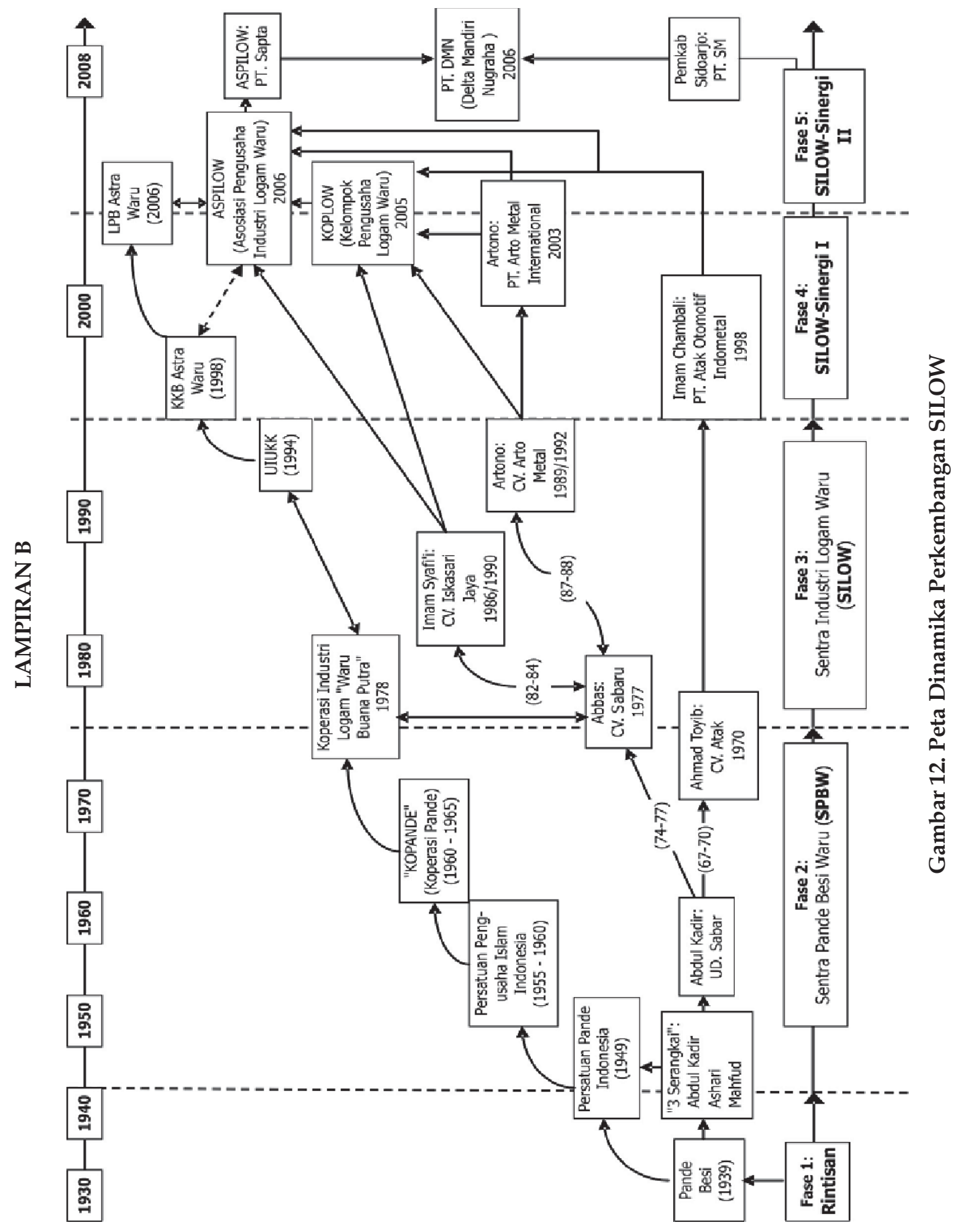




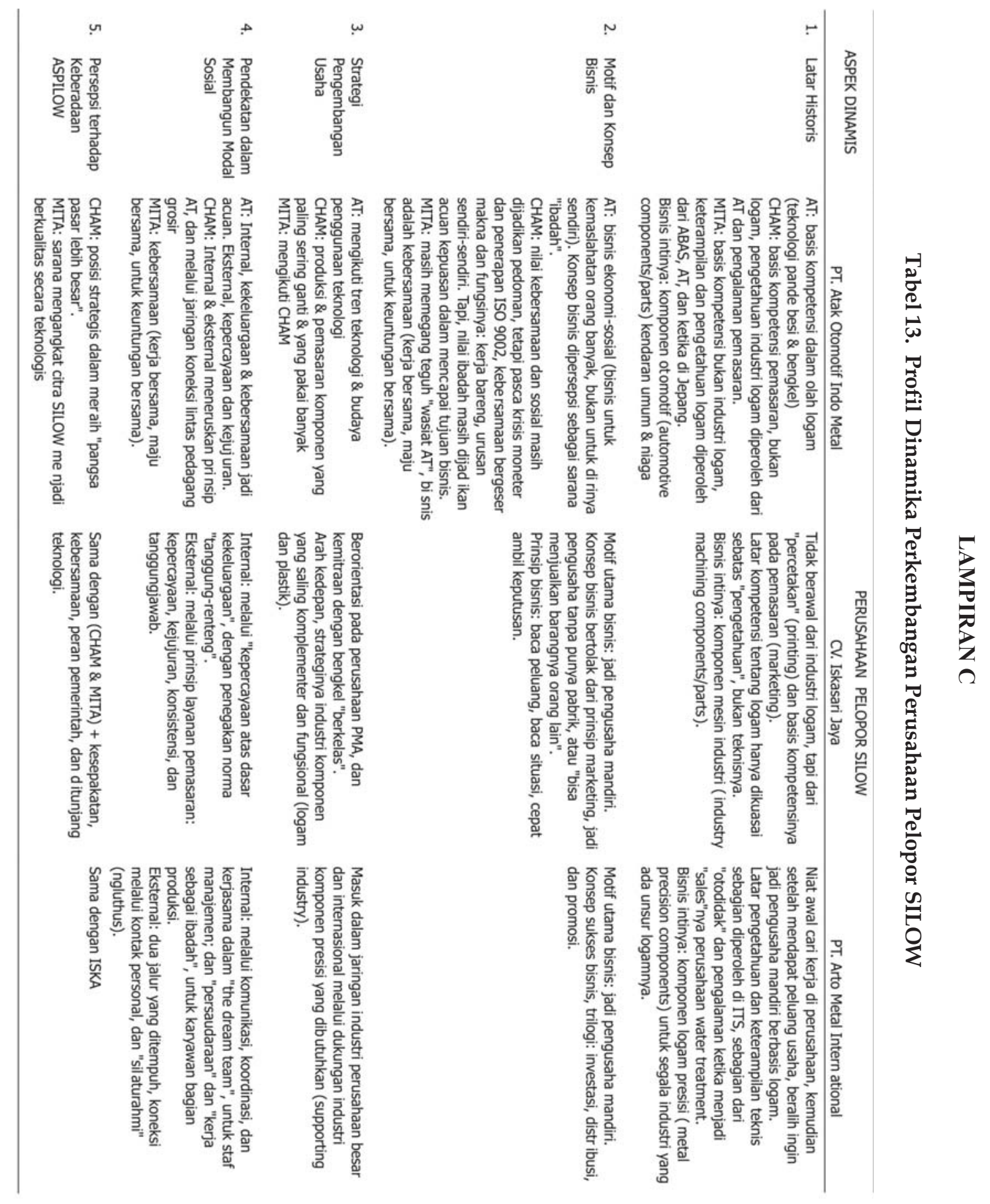

